Illinois State University

ISU ReD: Research and eData

Theses and Dissertations

$3-29-2020$

\title{
The Magic Of Teaching And Assessing Writ[rid]ing
}

Kristina Koehler

Illinois State University, kristina.lesette@gmail.com

Follow this and additional works at: https://ir.library.illinoisstate.edu/etd

Part of the Liberal Studies Commons

\section{Recommended Citation}

Koehler, Kristina, "The Magic Of Teaching And Assessing Writ[rid]ing" (2020). Theses and Dissertations. 1231.

https://ir.library.illinoisstate.edu/etd/1231

This Thesis is brought to you for free and open access by ISU ReD: Research and eData. It has been accepted for inclusion in Theses and Dissertations by an authorized administrator of ISU ReD: Research and eData. For more information, please contact ISUReD@ilstu.edu. 


\section{THE MAGIC OF TEACHING AND ASSESSING WRIT[RID]ING}

\section{KRISTINA KOEHLER}

\section{Pages}

Theories of hermeneutics (Moss) and complementarity (Broad and Boyd) claim that human understandings deepen when inquiries are informed by multiple perspectives. This thesis renders two distinct but related pedagogical enterprises - the teaching of writing and the teaching of horseback riding — reciprocally illuminating and complicating. As a result, the Elbovian "magic" of teaching, assessing, writing, and riding has come to light: the delicate humanity and intimacy of our work in both "communities of practice" (Star). My argument calls teachers to embrace this "magic" in our classrooms by confronting fears that both we and our students experience and by implementing more humane teaching and assessments practices. Doing so is essential if we wish to gain the trust we need to be create change in our classrooms and in the conversation about reimagining our large-scale writing assessment. I specifically argue for the design of a large-scale portfolio assessment that is evaluated by teacher experts and provides "educative" feedback to students as part of their ongoing development as rhetorical writers in our democratic society (Wiggins). Other teacher-researchers ought to undertake their own hermeneutic, complementary projects of reciprocal illumination in order to alter our communal "vantage point," allowing us to see our deeply human craft of teaching and assessing writing in new and uniquely valuable ways (Star).

KEYWORDS: teaching; writing; assessment; riding; fear; humanize 
THE MAGIC OF TEACHING AND ASSESSING WRIT[RID]ING

KRISTINA KOEHLER

A Thesis Submitted in Partial

Fulfillment of the Requirements

for the Degree of

MASTER OF SCIENCE

Department of English

ILLINOIS STATE UNIVERSITY

2020 
(C) 2020 Kristina Koehler 
THE MAGIC OF TEACHING AND ASSESSING WRIT[RID]ING

KRISTINA KOEHLER

COMMITTEE MEMBERS:

Bob Broad, Chair

Sarah Hochstetler 


\section{ACKNOWLEDGMENTS}

I would like to thank the few folks in my life who've supported my irrational love of horses and also that sea of people who told me I'd grow out of it someday and pushed me to pursue higher education and a "big girl job.” Ha! I've done both here.

Dr. Bob Broad is the one who pointed this intersection of my identities out, nonchalantly during a meet-and-greet in January of 2018, when he asked how my riding competitions were assessed. Bob provided enormous amounts of timely, educative feedback that nauseated me, challenged me, encouraged me, and ultimately made this piece of writing whole.

My students, both in riding and writing, are largely to thank for the ideas included here, as I spend most of my time thinking and writing and talking and riding in their spaces.

Thank you to all of my riding coaches, who've wiped snot off my face and brushed dirt off my breeches. You taught me something that helped me even when this thesis "bucked" a little; we get back on and keep riding, or writing, anyway.

My Grandma and Grandpa, farmers from central Illinois, gave me an incredible work ethic and pride and have always supported "more" when it comes to my teaching career. "Remember no matter where you go or what you do, Grandma loves you."

Glen Mulvaney served as my life-partner during this writing process, making sure our basic needs were met so that I could go to "thesis-land" or the barn and usually both.

Dr. Sarah Hochstetler was instrumental in the development of the ideas included herein. Thank you for attending my Illinois Association of Teachers of English presentation way back when and asking more questions that led us here.

K. K. 


\section{CONTENTS}

Page

ACKNOWLEDGMENTS

FIGURES

CHAPTER I: ARENA, CLASSROOM: THE LEARNING SCENCES 1

Methodology 1

Magical Views

Coming Together and Pulling Apart: Inside the Arena and Classroom 5

Choice (or lack thereof) in Objectives, Instructional Strategies, and Instructor 5

Role of the Teacher/Coach 9

Creating More Magic, More Humans 11

CHAPTER II: CONFRONTING FEAR: THE SILENT PARALYZER IN WRIT[RID]ING 13

$\begin{array}{ll}\text { Overview } & 18\end{array}$

What's So Scary, Anyway? $\quad 21$

Fear of Being Dismissed for the Sake of Curriculum 21

Fear of (Well-Meaning) Dishonest (Pressured) Writing Teachers 23

Fear of Grades and Grading $\quad 24$

Fear of Reader Response $\quad 26$

Riding Instruction’s “Craft Workshop Approach” in the Writing Classroom 27

Strategies to Confront Fears in the Writing Classroom 28

Creating "Nervous Fear" in Strategic Writers 28

Circles to Normalize Writers' Fears of the Writing Process 35

Humanizing Grading Processes Through Conversations about Writing 37 
Conclusion

CHAPTER III: ENOUGH HORSING AROUND: RAISE THE BAR FOR WRITING

$\begin{array}{ll}\text { ASSESSMENT } & 45\end{array}$

The Flawed Format of the SAT and Choice-Driven Portfolios in Eventing 47

Preparation to Condition Fit Writers and Riders $\quad 50$

Issues of Access with Preparation Practices in Both Spheres $\quad 52$

Writing Results: "Miseducative" SAT Scores from Underqualified Scorers 54

Riding Results: "Educative” Scores from Highly-Qualified Judges 57

During the Assessment: "Ringside" Coaches $\quad 60$

Will “Objectivity” Continue to Hold Us Back?

$\begin{array}{ll}\text { Trust Our Teachers } & 62\end{array}$

$\begin{array}{ll}\text { Conclusion } & 64\end{array}$

CHAPTER IV: CODA: Humans are the magic $\quad 66$

$\begin{array}{ll}\text { Writing Matters } & 68\end{array}$

$\begin{array}{ll}\text { Essential Values in Our Writ[Rid]ing Spaces } & 70\end{array}$

$\begin{array}{ll}\text { What's Next? } & 73\end{array}$

Emotional Labor and Financial Stress of Being a Teacher and Equine Professional 73

$\begin{array}{ll}\text { Teacher as Writer, Expert, Learner } & 74\end{array}$

Social Justice in Writing and Riding $\quad 75$

Gamification in the Writing Classroom $\quad 76$

$\begin{array}{ll}\text { Freewrit[rid]ing } & 77\end{array}$

$\begin{array}{ll}\text { Hop On: Come Write With Me } & 78\end{array}$

$\begin{array}{lr}\text { WORKS CITED } & 80\end{array}$ 


\section{FIGURES}

Figure

Page

1. Jenna using the lunge line to build confidence at the trot

2. Sparty stealing my heart in his pasture

3. Jenna cantering Trigger at her next lesson

4. Me experiencing "nervous fear" when jumping Max

5. Me and "All That Glitters" competing at novice level USEA events

6. Princeton Review's self-proclaimed “expert-led” SAT preparation

7. SAT scorer job description from Pearson

8. Pearson's “scoring eligibility" clause 


\section{CHAPTER I: ARENA, CLASSROOM: THE LEARNING SCENCES}

I am a teacher of writing by day and a riding coach by night. I split my time between wearing slacks and breeches, holding a pen and reins, carrying books and muck buckets, picking at brains and hooves. I move between desks and power cords in kitten heels before tromping through mud in my muck boots on my way to fetch an ill-groomed lesson pony. My worlds often seem separated by their logistical differences, barn and classroom, and by who I am in each space, teacher and coach. However, I recently discovered that in both roles, I shape powerful and beautiful movements in my student writers and riders. Both activities are deeply professional; both personal. In this thesis, I will explore how the teaching and assessing of writing and riding mutually illuminate — and also complicate — each other. I will seek out surprises, tensions, and contradictions and trouble interconnections between the complex dynamics of each learning environment.

\section{Methodology}

This particular intersection of my teacherly identity and research may initially feel "contradictory or chaotic" (Broad 11); however, scholars from multiple fields, like Susan Star in technology research, have been "using multiplicity as the point of departure for all analysis" instead of continuing to "add perspectives to an essentially monolithic model" (Star 86). Bob Broad and Michael Boyd, scholars in writing, make a similar argument for employing "the theory of complementarity" in humanities research, where we can uncover new and valuable findings by comparing spheres that "share parallel epistemological problems as well as solutions" (11). Specifically, they invite the field of physics to complement the ongoing conversation about rhetorical writing assessment and shed new light on what reliability really 
means both in science and writing. In this case, I am employing the "theory of complementarity" by inviting riding, a specific "community of practice," to the table to newly illuminate and complicate our collective understanding of teaching and assessing writing - and vice versa (Star 102).

Pam Moss, another scholar in writing assessment and hermeneutics, shares the belief that "multiple and varied sources of evidence" should be collected from written texts and lived contexts to help writers and their readers to arrive at well-rounded conclusions (7). In this case, my real context, my "vantage point" as a researcher is my own embodiment and enactment of teaching in both fields (Broad 11). This allows me to be "somewhere in particular" as a researcher: in arenas and classrooms where learning and assessment happens all around me (Haraway 122). By situating myself this way, Star says I "refuse to discard any of [myself] in an ontological sense" (Star 82) and instead use my "extensive knowledge of [the] learning" and teaching "context[s]" (Moss 7) as a "source of power" (Star 82), sort of like a superpower, that allows me to see our craft through a new lens.

In practice, I've explored the teaching and assessment practices within writing, as many scholars have done for decades and are doing as I write. However, what makes my argument uniquely valuable is its being situated somewhere new, at the intersection of riding and writing instruction and assessment, the spaces that envelop me each day. Throughout the research process, I've been moving through and between each sphere as a teacher, a writer, a learner, a rider, and a coach and doing so has "substantially alter[ed] the evidence itself," as Broad and Boyd predicted, and allowed new connections to form organically through my daily experiences. It's as if we have all been living in the same town for years, but now I've invited you onto my particular rooftop to analyze the parts of our shared city, and together, we can see familiar 
structures from new angles and identify areas deserving of celebration and places we can collectively improve.

In a larger sense, this "theory of complementarity" is essential because it connects isolated parts of our individual identities and communities and allows us to "create metaphors bridges" that "bring worlds together and hold them there," to "heal or create, erase or violate, impose a voice or embody more than one voice" (Star 102). Donna Haraway echoes that sentiment by saying that "finding a larger vision" means "joining partial views and halting voices into a collective subject position that promises a vision of the means of ongoing finite embodiment, of living within limits and contradictions - of view from somewhere" (Haraway 122). I hope to provide a piece of this larger vision for the teaching of writing and invite other practicing teachers to join in the "patchwork" that is shaping more ethical, responsible, inclusive, humanized spaces for the teaching and assessing of writing and riding (Star 82). In other words, I want to be invited onto your rooftop to see what our city looks like from your vantage point too. This is exactly the deeply personal, contextualized work that I call for in our writing classrooms and large-scale assessments as well: we must actively seek ways to make ourselves and our students whole and healed and connected through the intimate acts of teaching and riding and writing and assessing, and in this case, researching.

\section{Magical Views}

Before I begin this complementary work, I must trouble my own use of the word "magic" to describe the work we do in our classrooms and arenas. The inception of this term to describe our work was born in Peter Elbow's “magical view of language" that emerges late in his book Writing With Power, as he tries to pinpoint how good writers infuse their work with "buzz," 
"bang," "life" (Writing With 357). His explication of the magic of language "in a nutshell, is that the word is a part of the thing it stands for - the word contains some of the juice or essence or soul of the thing it points to" (Writing With 358). Essentially, Elbow believes the magic of words is that, when they are deployed with power, they "give us movies in our head" that transform readers' beliefs, when literally, all words are merely scratchings on paper (Writing With 365).

That phrase "magical view" resonates with me, not only as a writer, but as a teacher and a rider too. In my mind, magic has to do with transformation that doesn't make much rational sense but that we willingly suspend our disbelief for, like how readers allow their vision of Kings Cross Station to be transformed in their minds to include a magical Platform $93 / 4$ for Harry Potter. In this thesis, I take a "magical view" of riding and teaching too. Below is my attempt at articulating what I mean by that.

- My magical view of riding, in a nutshell, is that both the horse and rider are lost in the process of riding, and somehow they become something new, "centaurs" (Emerson 120). The rider becomes "an integral part of the living, breathing horse, almost as if the spinal column of the horse merges with the spinal column of the rider to create one entity" (Emerson 120). Together, the horse and rider can create movements that neither were capable of creating alone.

- My magical view of teaching, in a nutshell, is that when a teacher guides, coaches, mentors a student to embody and enact a set of skills, beliefs, or values, both parties become teachers, both learners as part of a larger cycling and recycling of past, present, and future understanding in our world. When learning really "takes" or "sticks," the souls of both teachers and students inter/ex/change to create knowledge. 
- My magical view of assessing, in a nutshell, is that a human reader must allow themselves to be transformed by the words on the page and then articulate/evaluate the "subjective, shifting, anything but predictable" movie that was created in their mind by the simultaneously magical words (Reimagining xxi).

Elbow describes the good writer as "put[ting] a successful hex on the reader," and I think the effective rider and teacher and assessor does the same thing; all three parties "must enter into the thing or merge your soul with the soul of the thing...." Riders must enter the soul of the horse; teachers must enter the souls of their students; assessors must allow the words access to their soul. That intimacy of transformation is what magic means to me.

The trouble with magic, though, is it's not respected or trusted in a society that is obsessed with objectivity and scientific explanations - magic is just for fun! Elbow knows this too, hence his attempt to be "reasonably magical" and define the magic stuff in quantifiable, communicable, transferrable ways. He wrestles with how to put more magic into words as a writer (Writing With 359). In this thesis, my goal is to similarly poke at the magic in teaching and assessing and see how we can create more of it. How do we teach in a way that "bang," has life that "takes" in our writing classrooms? How do we become assessors that have allowed our students' words to “bang," have life that "takes" in our minds as readers (Writing With 357)?

\section{Coming Together and Pulling Apart: Inside the Arena and Classroom}

Choice (or lack thereof) in Objectives, Instructional Strategies, and Instructor

As a teacher of riding, I teach private 45-minute lessons, which allows me to tailor the learning objectives and instructional strategies to each horse and rider's "needs, desires, and 
goals" (Cochran 52). I first "evaluate what they know, figure out their learning style and how they listen to and interpret [my] instructions" and "set goals accordingly" (Cochran 151). Because the lessons are private, I can provide "continuous feedback" to students that tells them in real time whether they are closer or farther from their riding goal at any particular moment (Reimagining 8). These goals all relate to communicating and shaping movement with the horse, a party whose presence heightens the stakes for riders and teachers of riding and makes the learning immediately purposeful as it impacts change in the animal and prevents the rider from coming in contact with the ground unexpectedly. Because of these stakes, I never "hurry" a student into the next level. Wallace stresses building "safety and confidence first," at all times and not "bullying" riders into something they're "genuinely frightened" to do (Wallace 95). ${ }^{1}$ Sometimes that means a rider needs to stay at the same level for multiple lessons due to physical fitness, body control, mental strength, interest, etc., but if that is what makes an individual student "tick" and keeps them safe, that is exactly what we do (Cochran 246). We simply move on when the rider is fully ready.

Occasionally I teach group lessons, with a maximum of six riders, but "you have to have eyes in the back of your head and be able to watch everyone the same, so that everyone gets equal value from the lesson" (Cochran 160). The group lessons that fail are the ones where "the group is too large, or has too large a variety of skill sets, or too large of a variety of ages in the group" (244). In this "failed" lesson, "no one learns anything and the entire ride is in chaos" or "riders... get bored and not enjoy the lesson" (244). I have been a part of both chaotic and boring lessons as a teacher and rider, and it is incredibly frustrating from both perspectives. As a teacher, I can be left feeling like not all riders were able to meet my objective because I could not

\footnotetext{
${ }^{1}$ The complex role of fear in riding and writing instruction is further explored in chapter two.
} 
provide enough individualized feedback. As a student, I can be left feeling like the money I spent for the instruction was wasted on other riders' development.

Because of this element of financial investment, I have found that riders and their caretakers that continue to pay me a high-rate for instruction ( $\$ 35$ for 30 minutes; $\$ 60$ for 60 minutes) generally have a high-level of respect for my teaching style. As the instructor, I get to choose the instructional strategies that I believe, in my expert opinion, will work best for that particular rider on that particular horse on that particular day for the objective that I have set. It is important to note that this trust that riders and parents have in me is based on my 11 years in the saddle, seven of those casually, four of those competitively. While I have paid for lessons with many excellent coaches throughout the last decade, I have no formal education, certification, degree, etc. to show for my equine knowledge. I have a few ribbons hanging on my horse's stall, a homemade Facebook page with a few positive reviews, and flimsy business cards to prove my credibility as a riding instructor, and that's pretty much it. That's enough for paying customers in the riding community.

My experience teaching in my writing classroom looks different in several logistical ways. I see a total of 160 student writers throughout the six 49 -minute periods that make up each weekday, averaging 27 students per class period. They each have a desk and a school-issued Chromebook issued to them. In sophomore English, we have a department curriculum that we are assigned to teach and learn that is standardized between the three teachers who teach the course. In that way, each student has common objectives to meet and assessments to take, regardless of their ability-level, interests, or needs, that are set by an outside force. As their teacher, I do my best to differentiate instructional strategies to help each of the 150 students I see each day meet or exceed those expectations. Unfortunately, the reality is that some writing 
lessons "fail," in the same way group riding lessons do: with groups this big and ability-levels and interests so varied and common objectives pre-determined, it is inevitable that some students will become bored, the classroom atmosphere occasionally feels chaotic, and sometimes no one learns anything at all. Other times, students are left feeling that the writing we are required to do is "trivial and inconsequential" and leaves them asking, "What's the point?" (Dean 17, 51).

At the end of the day, I, as their teacher, feel pressured to move on to the next set of objectives when the scope and sequence says I should, regardless of student readiness. I wonder what we risk in terms of "safety and confidence," two core values of teachers of riding, by regimenting the pace and scope of our curriculum? If a rider is not proficient in a specific skill set, it would be dangerous to "bully" them on to the next objective. For example, if a student is not confident steering a horse while the instructor is walking alongside, pushing a shaky rider to trot off in the arena alone could cause the rider to fall, injuring their physical or emotional wellbeing and discouraging them from riding in the future. How often have our student writers been "bullied" into writing tasks that they are not equipped for or confident in, and how have their self-concepts as writers been injured? It is no wonder that by the time students walk into my classroom as sophomores in high school, many are reluctant and resistant to write. They have become jaded by writing experiences that have "genuinely frightened" them.

As opposed to my lack of formal qualifications as a riding instructor, I have spent the last seven years enrolled in a state university, earning a bachelor's and a master's degree in the teaching of English. I have spent summers, weeknights, and weekends traveling to courses, conferences, and professional development opportunities to learn the best practices in the teaching of writing. I even spent a summer abroad, studying English education practices in Japan and England. I have also gained four years of teaching experience in a public school setting, 
where I am formally evaluated each year. My circumstances are not unique, as all certified teachers are required to continue developing professionally in order to keep their state license. Despite teachers' extensive professional qualifications, students, parents, administrators, school board members, fellow teachers, and community members, feel empowered to question, challenge, and sometimes demean writing teachers' classroom practices (i.e. too much homework, not enough points in the gradebook, too slow on returning grades, not enough feedback, too energetic, not interesting enough, etc.). In other words, riding coaches are afforded more respect and trust than teachers of writing.

\section{Role of the Teacher/Coach}

In both riding and writing, scholars discuss the complex role of the teacher, and there are commonalities in what our students expect from us. One common expectation is that the teacher will be nurturing, non-conflictual, "gentle, caring, and supportive," "sort of like a mother's love" (Jarratt 111; Emerson 50, 55-6). Under a "teacher-mother's" care, the writing classroom "becomes a safe environment where everyone feels nurtured and able to speak and write, where conflicts are resolved and everyone remains connected" (Buffington 2). Similarly riders feel "secure, happy and confident" (Wallace 92) when their coach is "nice," "kind, "fair," "positive," and "enthusiastic" (Wallace 17, 24). As a form of classroom management, "mom" is likely to use "reward authority" in which she gains respect by granting positive attention, encouragement, or more privileges to well-behaved writers (Esmaeili 4). The motherly riding coach should also "encourage and not dishearten" and "praise the effort[s]" of riders (Wallace 29, Cochran 80).

However, both fields recognize that teachers and coaches don't always fit this “teachermother" role, and instead, some are more like "teacher-fathers." This role is characterized by 
masculine "aggression and adversarial relationships" with students and is ultra-focused on content and evaluation (Jarratt 112, Buffington 2). This "fatherly" riding coach might "shout, criticize, and bellow like Marine Corps drill sergeants" and use the "shut up and ride" method (Emerson 50,47). This teacher is likely to use "punishment authority" as a form of classroom management by removing privileges and attention from students and would likely "kick your lazy butt!" in the saddle (Esmaeili 4; Emerson 130).

Riding professionals stress "there is not a right - or wrong - way to coach. It's what gets the best out of you and teaches you the most" (Dutton 9). Each individual coach's "personality and style" and rider's "needs, desires, and goals" are respected and embraced (Dutton 9; Cochran 52). Riders have the luxury of "quitting the team" if they don't feel that the specific coach is able to "impact... knowledge" to them personally (Emerson 53, 47). In other words, the student has chosen to attend the lesson at that particular time with that particular coach, and if they do not want to continue riding with that coach, they can choose not to. As a rider, I have experienced that multiple times; if a coach is too harsh or explained too much too fast or did not make me feel productive, I have chosen not to go back to them. Likewise, as a riding coach I have chosen not to continue teaching a specific student if their goals or learning styles are not ones that I can accommodate. Unlike the riding community, neither the teacher nor the student writer nor the caretaker can discontinue instruction if they do not "vibe" with that particular instructor or student. Participants in public writing classrooms are stuck with each other for the semester or school year, for better or worse, and that breeds a unique challenge for teachers. 


\section{Creating More Magic, More Humans}

Through honoring this intersection of my identity and exploring how each sphere illuminates and complicates the other, I've discovered that our classroom and assessment spaces in writing need more "magic" to be truly effective: what I've discovered to be the unexplainable, unquantifiable humanity involved in the processes of teaching and learning and riding and writing and assessing well. In the chapters that follow, I consider fear's role, an often invisible and ignored human emotion, in each learning environment and explore how to eliminate it so that writers and their teachers can progress with "safety and confidence first, at all times," like riders and their coaches do (Wallace 95). Then I argue that the teaching of writing must modify their large-scale assessments to be more humanized and educative, using a national assessment of riding as a model that honors trusted teacher experts as evaluators.

At the end of the day, "we write," and ride, "because we're human, and writing," and riding, "is a way of seeing and feeling and hearing, a way of asking and knowing, a way of creating and making sense, of expressing and communicating" (Reimagining 110). Teaching and learning and assessing in these spheres is deeply personal, deeply human, and deeply important and comparing the complex dynamics of each field can help work towards the goal of promoting "the healthy and sustainable growth of young writers within an inclusive and equal democracy" (Reimagining 51). ${ }^{2}$ We can accomplish this by rejecting the inherent disconnection in our schools and assessments that has become twistedly normal by viewing writing "as a thing, texts to be produced and evaluated" in factories by an "essay scoring machine" (Mathieu 175; Reimagining 21); instead, as Yagelski argues, we must foster the love, the mania of "the act of

\footnotetext{
${ }^{2}$ See chapter four for a detailed exploration of the stakes of writing in our world today.
} 
writing, the experience of writers writing" and teaching and growing "together" in our classroom and assessment scenes, like riders do (Mathieu 175). 


\section{CHAPTER II: CONFRONTING FEAR: THE SILENT PARALYZER IN WRIT[RID]ING}

Jenna, a fourth grader with over a year of riding experience, sat sobbing on Trigger, a beloved horse she's ridden for months. The tears came at the end of her hour lesson. We'd worked through the initial stiffness that she carries into lessons sometimes. Her shoulders had relaxed, her legs had softened, her balance was secure, and she was ready to canter, Trigger's

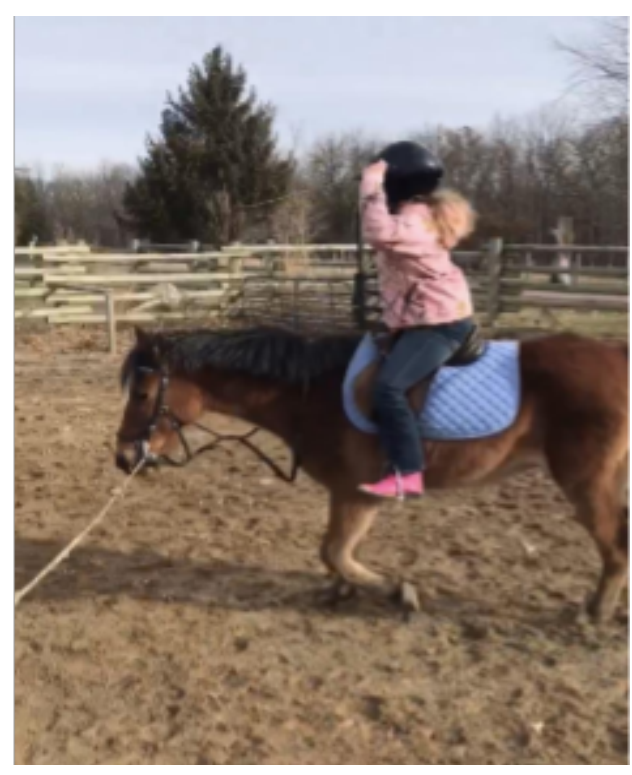

Figure 1: Jenna using the lunge line to build confidence at the trot top speed. I was proud of the way I'd learned the

particular strategies necessary to relax Jenna enough to control her position. I secured Trigger on a lunge line, a device that allows me, as her coach, to steer and stop the horse while Jenna learns how to navigate this new, faster gait with Trigger. This is a confidence-building strategy we've used since her first lesson. It's a small way of holding her hand and not letting go, until she's fully confident in her own ability to communicate with Trigger alone.

Jenna had cantered many times before, never with poor results, but this day, she began sobbing, hysterical about the idea of pushing onto the next gait. I try on a few different voices: an encouraging, "just breathe"; a questioning, "what can we do to make you feel better?"; a stern, "You've done this before, so you can do it today"; and finally, a defeated, "If your choice is to end our lesson without cantering today, there is nothing I can do to change that." Regardless of the approach, Jenna's tears raged inexplicably on.

"I," gasp, “can't," gasp, "breathe," gasp. "I don't know what's wrong with me!" More sobs. "I'm not," wipes snot, "kidding," gasp. "And my stomach really hurts!" 
Jenna's mother stood on the sidelines of the arena, similarly puzzled about the unexpected meltdown. It's true that Jenna's confidence has always been shaky, but we'd worked so hard to prepare for this moment. She was ready, and I knew it.

“Jenna, I'm not sure why you're reacting this way. I believe you can do this and so does your mom. But if you truly can't canter today, only you can know that, and I trust you. We can try again another day."

We ended the ride without cantering; we'd try again next time.

The news that Julia, another working student for the summer, fell off Sparty was buzzing around the barn. I was too busy throwing hay and bringing in horses to hear, until my name was mentioned.

"Yeah, Kristina and Ellen are like the only ones who can even ride that horse," Janelle said with a bit of an eye roll. She'd been the favored working student for the past year, and we'd been passively (yet aggressively) sorting out power dynamics since I arrived the previous month. She was winning.

“Wait, what are we talking about?” I chimed in. "Sparty?” He was a grey thoroughbred gelding who was the equivalent of my Grease-style summer love. Tall, handsome, silvery, young, smart, and definitely the most powerful animal I'd ever sat on.

"Yeah, he reared up on Julia a bit ago, and she bailed. Ellen had to get on him."

“That's weird,” I said, still processing Janelle's well-intentioned (maybe?) gossip. "He’s never reared or bucked or anything naughty with me." 
"That's because you and Ellen are like the only two people who can ride him without falling off or crying." I'm pretty sure Janelle rolled her eyes again at this point, but she looked away just in time, so I couldn't be sure.

At this point, a small pack of barn rats had gathered to hear Janelle talk about her negative experiences with Sparty.

“Who Sparty?” Ellen said, as she walked by toting a saddle back to the tack room. Her presence shook the barn rats as they all followed her with their eyes. She's their idol and mine too. We all want to be her when we grow up. "Maybe you just can't ride, Janelle? He's great with Kristina." She smiled coyly while continuing to walk towards the tackroom, saddle in arms.

Janelle made sure to get the last word. "Ha ha, you're funny, but maybe your horse is just an asshole!"

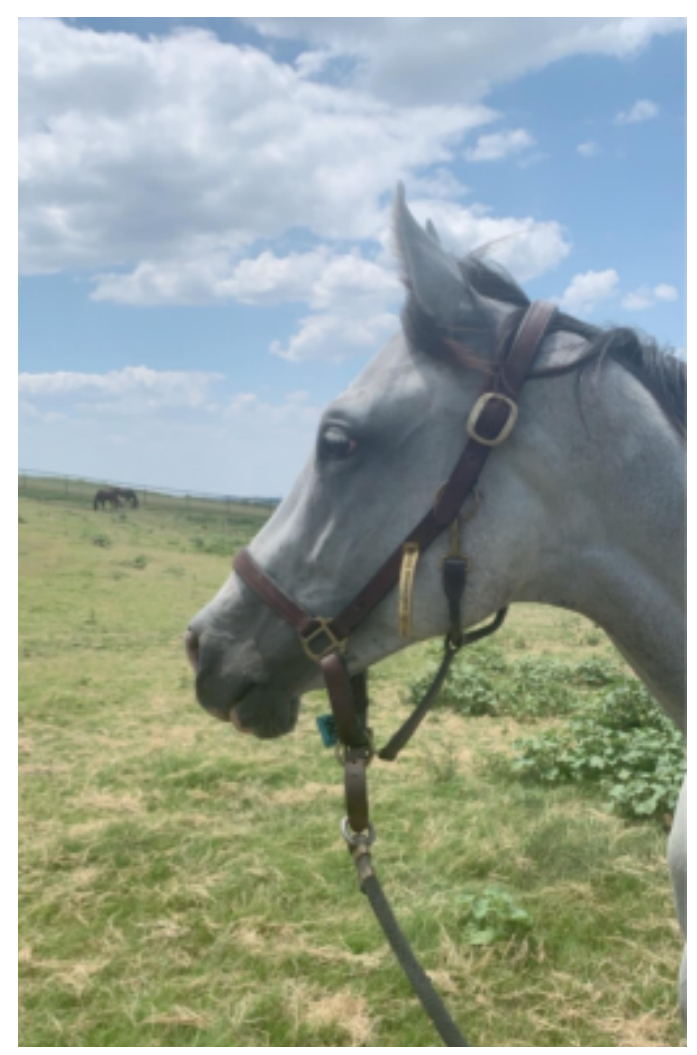

Figure 2: Sparty stealing my heart in his pasture

I carried on with nightly chores with a pit in my stomach. Ellen is a top-level rider, and my skills were simply not anywhere near that caliber. In fact, I would argue that Julia was a stronger rider than me! What was I doing on a horse like Sparty if Julia and Janelle couldn't even ride him?

The following evening I was scheduled to ride Sparty in a jumping lesson, just like every other Thursday of the month. This was usually my most anticipated evening of the night: time with my favorite pony crush? Yes!! 
But no. Not tonight. I had been carrying the weight of insecurity since that exchange with Janelle yesterday. Ellen must believe in my riding if she let me have Sparty.... She must also secretly know that I'm not skilled enough, right? Because I'm not skilled enough! Right? Or am I? I am!

Right.

I did the thing that I'd taught myself to do over my riding career. I tucked in my polo a little tighter, grabbed a whip, and saddled Sparty up, despite my wobbling confidence.

I'm not a chicken.

I've never been a chicken.

I won't be a chicken.

As we started our warmup, I noticed my hands sweating, but it was just the Texas heat in July.

My breaths came a little faster, but it was just the fatigue of riding my seventh horse of the day.

"Kristina, push your hips back in your saddle! Go with him, go with him, go with him! Move your elbows. Move your hips! More leg! That's it!” Ellen bellowed across the arena, one command at a time before moving on to the next rider in our group lesson. The sound of her voice made me swallow a little harder. She knows I can't do this. She knows it.

Sparty jumped sideways when the boogie man mysteriously appeared and disappeared in the form of a shadow on the wall.

Jesus, shit, god damn.

"Ride forward, Kristina!"

I can do this. 
We aimed at our first fence, and I hunkered into my jumping position, hovering right over my saddle. "That's it, but get lower! You've got to get out of his way!" Ellen yelled.

Sparty launched over the second fence, over-achieving as always, and I felt my hips crash backwards onto his spine as we landed.

“You've got to land in your heels, Kristina! Stay in your jumping position until a few strides after the fence. Keep your own balance! He shouldn't have to carry your weight too."

I know, I know! Again, again.

Tighter and faster. Faster and tighter.

Stop. "I'm sorry, Ellen. I just feel really stuck in my hips today. It doesn't feel right."

"We don't have to fix it all today, but we can get it better than it is right now, " Ellen reassured me. "Let's go outside and jump some cross country fences, everyone!"

The group of horses that were inside for the first part of the lesson followed each other like soldiers into our cross country field, full of solid obstacles, ready for battle.

Okay, this is my redeeming moment. I can do this out here. We just did it last week. And the week before.

When it was my turn, I galloped Sparty at the first roll top. We got this. We got this. Moving, moving, moving.

Launching. Crashing. Rearing. Bucking.

Rear. Buck.

Falling.

Crashing.

Grey 


$$
\begin{array}{llllllllll}
E & v & e & r & y & w & h & e & r & e .
\end{array}
$$

Quiet.

"Kristina, are you okay???"

\section{Overview}

I offer these vignettes as two of the most memorable riding lessons I've taught or taken, and looking back, their significance really has nothing to do with the riding, learning, or teaching that happened for Jenna or me. Both lessons demonstrate the enormous fear that riders must address, despite ability level, when riding a real, live, powerful, intelligent being who provides instantaneous and attention-getting feedback and acts and interacts in complex and multi-faceted ways. I am making the assumption that most readers will be teachers of writing who may never have experienced this real fear when riding a horse, so I use these elements of storytelling as a research tool to fill you in about this particular aspect of riding and riding instruction.

For the sake of closure, it's important to know I was okay when I fell off Sparty, and I know now, after talking with Ellen and reflecting independently, that my body was so tense and rigid because of the fear of falling, like Julia had the previous day, that my hips were unable to hover in the saddle after the fences. Sparty bucked me off because he was sick of my rear bouncing into his spine, and that is totally understandable, dude! This was not a body control issue I'd experienced before this lesson, and it isn't one I held after. Although I'd been riding for a decade on the night of my fall with Sparty, I was paralyzed by the childlike fear Jenna had experienced and was unable to ride effectively, even though I'd done it a million times before. Jenna also recovered from her fearful ride when she came back a few days later for another lesson. As we groomed, I shared the story of the last time I cried during a bad ride a few months 
before, my ride with Sparty. We reflected

together about how our emotions

sometimes get in the driver's seat while

we're riding (or living), and we must

recognize them and learn to channel them

in a productive direction once we're able.

Sometimes we're able to do that

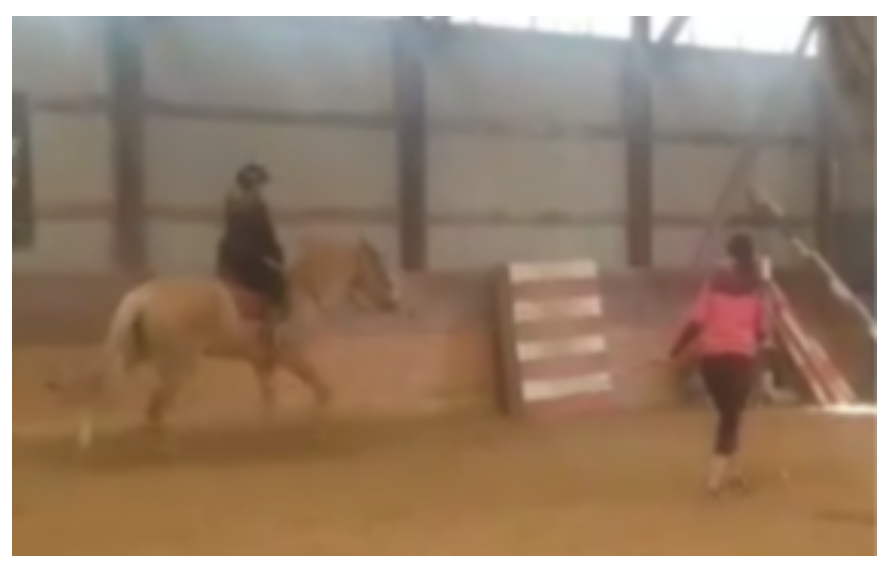

Figure 3: Jenna cantering Trigger at her next lesson immediately; sometimes it takes time, and that's okay too! Once mounted, Jenna cantered right away, reminding me of my own determination when I remounted Sparty the day after my fall. Jenna and I both conquered our temporary fear-induced paralysis, restoring the feeling of safety and confidence that is essential when riding, so that we could continue to progress as effective riders.

Helping a student confront his or her fears is commonplace in the teaching of riding due to the physical risks riders assume by mounting and controlling a 1200-ish-pound animal. My favorite coaches of all time have wiped tears off my face, have given me firm hugs when I've had a bad ride, a bad fall, or just a bad day. They've had that "sixth sense" that says when and how far to push to keep my "fragile" self-concept as a rider and person safe (Wallace 9; Cochran 152). Sometimes that has meant putting "knowledge and experience" and progress on the back burner while I cry or laugh or share (Wallace 17). I've tried to emulate that emotional responsiveness in my own riding program by "build[ing] a rapport" with my students, like Jenna, and as a result, I was able to recognize Jenna's intense inability to continue on with her learning that day. Instead, we delayed progress until she was able to process her emotions and be successful during her next ride. Ellen, on the other hand, had not developed a personal 
relationship with me by the day of my fall, and as an adult, I was much better at stifling my fear than Jenna was. In other words, Ellen's "sixth sense" failed her that day because I "bullied" myself into doing something I was "genuinely frightened" to do, and she didn't notice (Wallace 95). This observation is not meant to sound critical of Ellen, a highly effective and respected, upper-level rider and coach but instead, to demonstrate the dangers of missing the signs that a riding student is not feeling "safe and confident" (Wallace 95); I was very lucky to walk away from my accident with Sparty with a few sore muscles and in need of a chiropractic adjustment.

In riding, fear of the animal, of falling, of failure, of injury, of death, is easy to spot and calls riding coaches to recognize and address fear in themselves and their students as part of their daily practices in the arena. However, writing teachers have been asked to ditch "our emotions and our feelings at the entrance of the school building, like an abandoned backpack ditched at the door" (Thiel 39), and we've transformed our classrooms into "factories" that "worship" the production of "human products" via quick and efficient workers, our teachers (Reimagining 20; Williamson 57). In this current climate, teaching writing is viewed as a "relatively straightforward process" that needs to be monitored by other stakeholders in education to keep teachers "accountable" for their production rates, meaning "what is taught and how efficiently it is taught" on their production lines (Williamson 58-9, 69). What could possibly be scary about that? Naturally, we assume nothing, and so we don't confront our students' or our own fears because we've been told, and we believe, that they don't exist.

The reality is schools today have become "breeding grounds" for that exact climate of fear (Wachtel 91) that locks students' abilities to learn or write in the same way a fearful rider can't control the horse with a locked up body, brain, or heart. However, the riding coach has a distinct advantage because they can see the physical evidence of fear: the horse tells on its rider 
by not behaving in the intended way. In writing classrooms, fear manifests itself almost imperceptibly: we see students shutting down or shutting the teacher out, detaching themselves emotionally and intellectually, becoming apathetic and mistrustful. These signs of fear are easy to miss and theoretically could be ignored. Unlike riding, a terrified writer isn't going to die if their teacher misses the signs and never addresses their fears. But if, as Maja Wilson says, our goal is to promote "... the healthy and sustainable growth of young writers within an inclusive and equal democracy" (Reimagining 51), we must find a way to first see the unintended, and even well-meaning, "violence" in our writing classrooms (Embracing 148) that scares our students, and us too; then value, respect, normalize, and remove it.

\section{What's So Scary, Anyway?}

Fear of Being Dismissed for the Sake of Curriculum

The factory-model of education has forced teachers to focus on "what" we teach instead of "who" we teach (Murray 6). Instead of connecting with our students in meaningful ways, we “continually mov[e] and keep [our] mind and hands, as well as [our] students' minds and hands, busy" (Thiel 40). We post learning targets in visible spaces; we submit weekly lesson plans to administrators; we share common assessments between teachers; we vertically align our curriculum to ensure linear progression through departments; we update online gradebooks multiple times a week for parents; all to show the forward momentum in our classrooms. These are the invisible "gears in a powerful societal tracking system" that encourage teachers to "escape [the] classroom's complications and all the emotions that fill that space" (Reimagining 6; Thiel 40). Disregarding this element of "who" in our classrooms encourages a "lack of connectedness" and causes students to "behave defensively with us" as their teachers (Wachtel 
141). In the same way that I was not able to learn how to effectively position my body over a fence because I was guarding my body from a theoretical fall that Sparty might induce, students' development as writers is "stunted" by the tension between teachers and students when we subtly communicate that moving through our curriculum is more important than they are (Embracing 144).

One specific way we ignore the "who" in our classrooms is by miseducating students about the experience of "cognitive dissonance," a natural human reaction when new teachings contradict past beliefs that often causes negative emotional responses like "anger, despondence, contention, and apathy" (Backburn 60). An example of this is the way Jenna "shutdown" when the idea of cantering was too much for her to process on that particular day or when my selfesteem as a rider was challenged by Janelle's comments about Sparty. This resistance to learning ultimately was productive for both Jenna and me, and we were not shamed for having a bad ride. Instead, we were praised for our ability to reflect and process our emotions after the fact with our coaches and learn about ourselves as riders and people because of those negative emotions. However, in schools, teachers often treat these signs of cognitive dissonance as behavior problems in need of discipline instead of addressing them as normal, exciting parts of the learning process (Thiel 60). For example, many "Jennas" in my writing classroom, who have refused to complete a writing assignment after direct instruction and repeated prompts, made me feel forced to make a discipline referral without much thought and move along in my instruction with the rest of the class. In other words, when students become emotional, positively or negatively, we subtly communicate that something is wrong with them for acting outside of the "normative behavior" that slows the efficiency in our classrooms and that can cause students to fear their own response to learning (Williamson 62). This miseducation about the role of 
emotions in learning prevents Elbow's idea of "good learning” from happening where we are both "transformed" and "deformed": "We cannot learn something without eating it, yet we cannot really learn it either without being chewed up" (Embracing 148). To help students be "transformed" into confident writers in a democratic society, we must take the time to normalize the feelings they experience by being "chewed up" and "deformed" along the way instead of quickly and efficiently shaming and/or punishing students and creating fear of learning for the sake of our curriculum.

Fear of (Well-Meaning) Dishonest (Pressured) Writing Teachers

Another layer of this distrust between teachers and students stems from the "dishonesty" of most of our "artificial" writing exercises in schools (Rethinking 76-7). Students learn over time that their "the reader," usually the teacher, "does not ultimately care what the student has to say, nor, for that matter, does the student. The student's intention and the reader's reaction are practically nonexistent, and any assessment that follows is meaningless" (Rethinking 76). I'm thinking of the department-mandated essays that are currently sitting on my desk where students analyzed poems they did not select through the same canned lens - ew! I don't want to read or grade those essays, and my students definitely didn't want to write them. This writing is the prime example of "trivial and inconsequential" writing that leaves both me and my students asking, "What's the point?" (Dean 17, 51). I'm left to "babysit" and "bamboozle" my students into believing that I am "more committed to learning and rationality than [I] actually [am]" (Embracing 92). Students realize they're writing for "piece of paper," not a human being, outside of any rhetorical purpose, so it's no wonder their engagement and trust levels drop: they're being “conscious[ly] deceiv[ed]” (Rethinking 60, 76; Embracing 93). 
I would not consider myself a dishonest or malicious educator who is trying to pull the wool over my students' eyes or waste my own time in my classroom; so why are so many wellmeaning teachers, like myself, allowing themselves to be a part of this factory? Teachers fear the "institutional pressures" to be efficient, unemotional tools and machines in our classrooms and many are "simply trying to survive... concerned about being ready for tomorrow (and sometimes just making it through the day)" (Inoue 211; Murray 3-4). Keeping up with the demands that stakeholders in schools put in place to "monitor how well we're teaching or how tough our 'standards' are" have us on the "verge of tears," "just keeping [our] head[s] above water..." when planning, teaching, managing, collaborating, reading, responding, and evaluating student work (Inoue 211; Embracing 120; Murray 304). Additionally, many teachers feel stifled by the idea that "If I teach in such and such a way, I'll lose my job" (Embracing 76). Exhibit A: The poetry analysis essays I previously mentioned that I do not believe will benefit my students are on my desk because I fear losing my job if I go against the curriculum. Teachers may also hold "an unwarranted fear of things falling apart" in their classrooms and the consequence of having to justify the lost instructional minutes that slow their production rates (Embracing 71-2). This showcases how the distrust in our classrooms is mutual: both teachers and students must sit in the uncomfortable dregs of discomfort and dishonesty in this factory.

\section{Fear of Grades and Grading}

Fear of grades can also erode our relationships with students before they even begin. "The very fact that we must sometimes flunk students tempts many" students to "play it safe, drive defensively, not risk exposing themselves" to the person who will ultimately judge and maybe prosecute their performance and award a high-stakes grade (Embracing 144). This is one 
of the luxuries riding coaches hold: they are allowed to coach the rider and support them at competitions, but there is a separate "judge" who will award the evaluation. ${ }^{3}$ Because of this separation between their coach and judge, riders don't have to worry about their coach hurting them with a negative score or feedback, allowing a more relaxed relationship to develop naturally. In the teaching of writing, we must be both a "credit-giver" and the "teacher": “...the hurdle the student has to get over" and "the person who helps the student get over hurdles" (Embracing 88).

This binary presents a unique challenge for teachers of writing and can be equally fearinducing for them because they have to defend scores to students they have coached up to this point. Riding coaches have the luxury of stepping away from blame if the external judge doesn't like the rider's performance at the competition and gets to be "wholly an ally" to their rider once they return home and can improve based on the feedback (Embracing 144). Writing teachers must sit with their students before, during, and after the evaluation process, and this can cause teachers to become "cynical" and "defensive" about grading (Writing with Power 218;

Rethinking 31). When the purpose of reading student work "is to defend a grade, we do not apply any of our natural responses to text." Instead, we "look for mistakes, inconsistencies, and unclear thinking to justify which square in the matrix we will circle" (Rethinking 31). That type of onesided "doubting" of student writing, where we make a "systematic, disciplined, and conscious attempt to criticize everything no matter how compelling it might seem," fosters a negative relationship between us and our students, when their confidence as writers is already fragile (Embracing 257). Becoming a "slave reader" creates a cycle of violence in our writing classrooms, as we try to defend the grade we've given and students' writerly self-concepts are

\footnotetext{
${ }^{3}$ See chapter three for a further explanation of the coach vs. judge in riding assessment.
} 
torn down by doubt and negativity, that prevents real learning. As a result, both teachers and students draw away from each other, protecting themselves much like a scared rider does when bracing against fear of physical harm.

\section{Fear of Reader Response}

Students may also be paralyzed by the "fear of failure" or "fear of the audience" beyond their teacher (Murray 39; Writing Without Teachers 83). According to Elbow, “... when we write for 'real audiences'... the stakes are very high and we get too clenched," like me on Sparty the day of my fall when I failed to stop clenching my physical body. Both riders and writers have all had negative experiences with an "audience" before, whether that is a reader or a horse, and “their past miseries resurface as avoidance, depression, anger, rebelliousness, or grief” (Holaday 35). In order to fulfill the "deep human urge to protect what [we] appreciate from harm" (Embracing 146), we do our best to avoid (r)ejection from the horse or reader and "end up not wanting to share" with their audience at all. "Without realizing it, to feel the reader," or the horse, "as enemy: they've hurt us deeply time and again in the past, the dirty bastards" (Embracing 146; Writing With Power 144). Riding coaches recognize that if a student "tumbles" off the horse, "it is crucial that the child recovers confidence... as quickly as possible," yet teachers of writing often fail to even acknowledge the writing student has been hurt by a previous reader's response (Wallace 21). In the same way an insecure rider cannot learn to ride effectively without immediately restoring confidence after a fall, our student writers cannot possibly stop "clenching" long enough to produce effective writing if their past hurts from and current fears of reader response continue to be ignored. 


\section{Riding Instruction's “Craft Workshop Approach” in the Writing Classroom}

In riding instruction, coaches have what Williamson calls "operational autonomy" to set and assess instructional goals for individuals based on the highly-complex dynamics that go into teaching, rather than turning that responsibility over to people who do not have "direct and ongoing contact with students": legislators, administrators, school boards, parents, etc. (75). In practice, that means I have the autonomy to progress as slowly or quickly as I'd like with any given horse and rider combination as the expert coach, and I never feel pressured to "hurry" onto the next level (Wallace 95). This "operational autonomy" also means that riders and/or parents rarely question my instructional strategies. They assume that no matter what I ask the rider to do (ride around with their arms to the side, ride with no stirrups, sit the trot rather than post it, flop around like a monkey, ride backwards, sing their $\mathrm{ABCs}$ at the canter, etc.), there is an end goal that will be productive. As the respected instructor, I get to choose the instructional strategies that I believe, in my expert opinion, will work best for that particular rider on that particular horse on that particular day with the rider's goals in mind. I also get to measure the student's progress throughout the lesson and tell them in real time whether they are closer or farther from their riding goal at any particular moment.

This approach assumes that teaching and learning are "highly contextualized processes involving the abilities of individual students and their particular learning needs and goals as defined by themselves and their teachers" (Williamson 76). This is exactly the type of learning scene that Elbow says allows teachers to be "wholly an ally" to his or her students, rather than getting "bullied" by the largely outside forces that police the "what" in our classrooms (Wallace 95; Murray 6). When teachers and students have the "safety and confidence" needed to do their 
jobs well, they can "take risks, connect the self to the material and experiment" and restore the intimacy and spirituality of "genuine development or growth" (Wallace 95; Embracing 144).

A reality where we can emulate riding lessons to provide fully individualized instruction to each student writer's "ticks" in a public classroom seems completely unrealistic and out of reach, and that is not what I am advocating we do. However, much like riding arenas, our writing classrooms can become more "open, mindful, compassionate, and dignified" spaces that allow us to enjoy the "delicate human encounter" of teaching and learning and writing, "like love, like sex" (Embracing 120). This is not also not an argument for a loosey-goosey, easy curriculum: in order to truly support our students, “connect," "express," “comfort," “amaze,” "convince," "help," and "shape" in our writing classrooms, we must also uphold a high level of control and rigor, "contraries" in our teacherly identities (Rethinking xx; Embracing 159). I am interested in the ways that we, as teachers of writing, can emulate strategies of riding coaches that hold simultaneous spaces for trust and rigor that ultimately create confident writers who are able to address the fear of learning and writing and effectively engage in high-stakes writing scenes now and later, as essential members of our democratic society.

\section{Strategies to Confront Fears in the Writing Classroom}

\section{Creating "Nervous Fear" in Strategic Writers}

In riding, the element of the horse is, quite simply, scary, and even the best riders must have courage to mount an unpredictable, relatively enormous, animal. However, the element of fear is productive for riders. Emerson says, "You have to scare yourself a little to give yourself something to build on, but only a little" (How Good Riders 87). I can relate to this, as my current horse, Max, is a young, powerful, uneducated, huge thoroughbred, who intimidates me just 


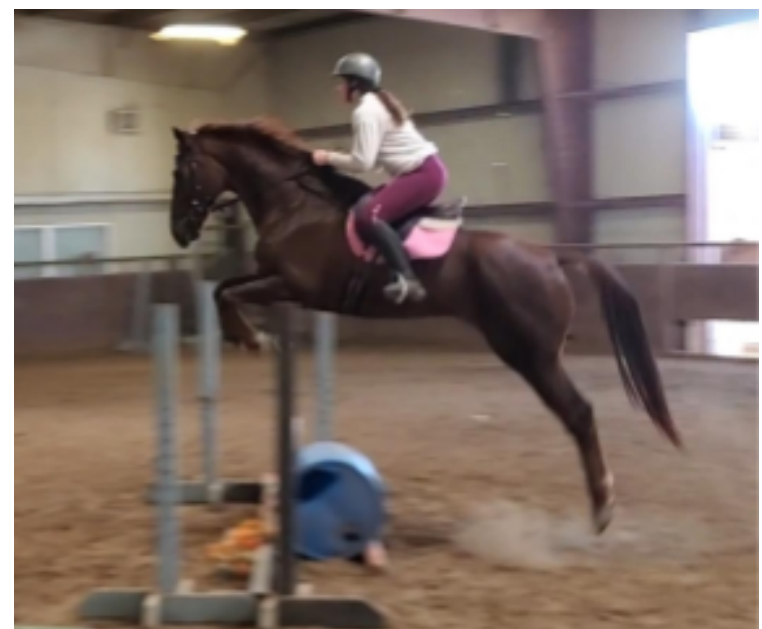

Figure 4: Me experiencing "nervous fear" while jumping Max enough to keep me highly focused and engaged while riding. This type of fear is also motivating to me because I know the "euphoria" I experience when Max and I successfully complete a task is “directly proportional to the fear I experienced beforehand" (Emerson 93).

However, not all fear in riding is positive. Emerson defines the crippling kind that I experienced when I rode Sparty as "real fear": the "fear of real injury, or the real possibility of imminent death" (Emerson 92). That fear is not at all productive, and it's what all riding coaches avoid when they call for "safety and confidence first, at all times" (Wallace 95). Riding coaches recognize that their students will not continue to ride at all if they are "genuinely frightened" because it is human instinct to protect yourself from harm (Wallace 95). On the other hand, the productive fear I experience with Max, is "nervous fear": "what you feel moments before walking onstage in front of a large audience to give a speech or act in a play" (Emerson 92). These nervous speakers or actors know their performance will be visible to a real audience and will impact them in some way, but they also know they have practiced and prepared for that particular moment. When I train Max, I know my riding will impact his movements in immediate and high-stakes ways, but I also can rely on the tools in my riding "quiver" to keep me out of imminent physical harm (Emerson 186).

In our writing classrooms, students experience "real fear" in a variety of ways, as I've detailed earlier, that cripples their ability to write productively. Just like riders stop riding if they stop feeling "secure, happy, and confident" (Wallace 92), we know that student writers will not 
meaningfully engage in writing tasks that they feel are deceitful, pointless, or frightening. Our task as writing teachers is to first eliminate students" "real fear" and then to instill "nervous fear." That may sound strange, but just like performers and speakers and riders, our student writers need to have real, live, kind-of-intimidating purposes and audiences who will be impacted by their writing; otherwise, they're writing to what Wilson calls a "faceless audience" that is "terrifying" (Reimagining 22). As I write, I'm trying to imagine myself practicing the biomechanics of riding without actually sitting on a horse.... It doesn't matter how straight I sit or how loose my hips are if there is not a real, live horse to respond to and be impacted by my movements. Similarly, it doesn't matter how proper or clear a student's writing is if there is no one to read it. As their teachers, we must create "horses" to focus and motivate and intimidate our students: real, live rhetorical situations in need of strategic writing.

Deborah Dean writes extensively about the idea of creating "horses" for our student writers in her book Strategic Writing: The Writing Process and Beyond in the Secondary English Classroom. She celebrates successes she's had in finding audiences outside of the classroom and provides many examples of specific assignments to get students engaging with real people outside of the classroom (49-50, appendix 7). Tracy Anderson also says asking for students to write to for "unknown audiences" outside of the classroom is "a critical motivator for [her] students' work" (16). However, not all texts, like a literary analysis essay, are written for an audience outside of the classroom, and Dean wrestles with what options teachers have for creating high-stakes opportunities for audiences within the bounds of the classroom community. One possibility is that teachers can create "imaginary audiences" for their students. For example, they could write a letter to the school board that never actually gets sent (Dean 51). Dean argues that these imaginary assessments only work if the student is being assessed on their ability to 
adapt the structure and diction for that intended audience. If students know the focus of the assessment is really just "to measure their written language skills" like every other paper they've ever written, they will not take the fake audience into real consideration and will "misconstrue" the point of the assignment, regardless of the teacher's attempt at creating a "horse" (Dean 51).

Larkin Weyand also takes a stab at the issue of audience in his article "Playable Case Studies." He suggests giving students problems to solve in a hypothetical, rhetorical situation. Weyend first "orient[s] students to the argumentative context" by showing students "the lay of the land for the writing situation" before "giv[ing] students an initial writing task" (80). He then "expose[s] students to contradiction" and encourages them to solve the theoretical problem through writing a document that defines the problem provided in the simulation and provides "a detailed plan to fix that problem" (81). This "inquiry-based" approach to writing can provide students "opportunities... to try out strategies and figure out how to fit them to their own needs" and "overcome a challenge with an appropriate and effective strategy" (Dean 6). This is similar to the way riders constantly solve "particular realistic problem[s]" that horses present at any given moment within a ride (Weyend 79).

Another option for creating an audience within our classroom is by being "more honest" about our own role as a reader: "If teachers are going to grade the writing, we can be honest about the fact that we are the primary audience - and we can ask students how considering us (teachers) as audience shaped the moves they made during drafting" (Dean 52). If we've established a climate of trust in our classroom that allows students to know us as humans, there is no need for students to write to us as if we are an "unknown audience," assuming we don't already know the title, author, genre and main summary of a novel we've read as a class (Blackburn 16; Dean 51). If we are "known" to students, they should write to us specifically as a 
real reader, and we can be honest with them about what that means for the particular writing occasion.

Other writers within the classroom family can also be used as a real audience for student writers, almost like "a group of amateur musicians who get together once a week to play for each other's enjoyment" (Writing Without 110). Elbow argues that developing writers need to share "with others in a supportive atmosphere" and "get responses from readers based on the readers' efforts to understand the writing and enjoy it and tell the story of what was happening in their minds as they were reading - rather than trying to judge it and figure out how to make it better," like what happens in traditional peer review settings that are guided by rubrics and checklists (Writing Without xix-xx). In a traditional, factory-style classroom, this type of environment where students are "open" and "listening" to each other's reading and writing experiences would not be possible due to the "instinctive clench" that takes over when students are asked to share their writing (Writing Without 112). However, in the spirit of rejecting the factory's demands, teachers should intentionally slow down and create opportunities for students to experience "nervous fear" of reader response by using a writing circle. The writing circle I am calling for is similar to that of the "restorative circle" (Zehr) or "teacherless circle" (Elbow) that articulates "a set of values, or even a philosophy... as part of the process - values that emphasize respect, the value of each participant, integrity, the importance of speaking from the heart, and so on" as students share and respond to writing (Zehr 64). To be effective, the restorative justice movement says the writing circle must include time for a daily warmup game or check-in question to get students in the mindset to learn or write and give them an opportunity to get to know each other (Illinois Balanced and Restorative Justice Project). This is the equivalent of what Wallace says is needed at the beginning of every riding lesson: "Ask how their ponies are, 
and if the children have had a good week at school, good holiday or whatever, just to get them chatting and part of the group" (39). Through this intentional daily practice in the writing classroom, students learn when to speak and when to listen to others and how to "take care of each other" and "take care of this place" by abiding to the norms of the circle and can also trust their peers and teacher when it comes time to share their writing (Better Than 55). In doing so, students need not fear the "extreme criticism or extreme praise" of unknown readers that previously might have hurt them because they can trust the honesty and intentions of the descriptions that other members of "classroom family" offer about their writing (Writing Without 83; Better Than 4-5)

Even though students will undoubtedly experience "nervous fear" when sharing their writing aloud in a circle, it will allow them to "bring the sense of audience back into [their] act of writing" and "discover the world doesn't fall apart" when a reader shares their experience with your writing (Writing Without 83). In fact, Elbow says this consistent, supportive feedback makes students more secure, independent, and fluent writers who are more attentive to their "own goals" for their writing. Our students can then "be interested in [peer] responses, and [they] learn from them, but [they] no longer worry about them. This nonworrying frees [their] writing" (Writing Without 126).

Perhaps part of the "nonworrying" that students experience in the writing circle stems from the honest, respectful, open feedback they're expected to offer to other writers as well. When students "must put [their] own responses out on the table" and "offer up [their] own reactions" to their peers" writing "as pure data - not defend or justify or even discuss them - just reveal them and let the other person use them for his own private purposes," they can learn how it feels to experience a real writer's writing, a part of the process students learn to fear when their 
teachers are the only ones who do it in moments of high-stake evaluation (Writing Without 140). They then share a mutual responsibility towards each other; "when a class," i.e. writing circle "works, you can feel people sticking up for themselves, making genuine demands and expectations of others that their time not be wasted, that they learn something" (Wachtel 63; Writing Without 113-4). The teacher then assumes the role of a nonthreatening "chairman" and simply "make[s] things run more smoothly, keep[s] an eye on the clock so that everyone's writing gets it fair share of time, help[s] people overcome unproductive habits like talking too much or too little, and generally keep[s] an eye out" while students read and respond to their writing (Writing Without 84). This "sense of attention, of tautness, of great energy" between and among students can be possible when an initial sense of community is built within the circle of writers as described earlier and can allow students to healthily crave, respect, and sometimes dismiss reader response instead of fearing it (Writing Without 112).

Regardless of the audience being outside or inside the classroom, real or imagined, both Weyend and Dean stress the importance of asking students to reflect on the usefulness of the writing skills they practiced within the given situation and the ways the rhetorical "tools" they used to "create a piece of writing" could transfer to other writing scenes in our democratic society (Weyand 81; Dean 8, xvii). These strategies students learn from writing for different audiences and purposes is much like adding tools to a riding "quiver" through spending "saddle time" with many different horses who present unique problems to solve (Emerson 186). In order to be truly focused and motivated, both writers and riders must "make something happen as a result" of the strategies they use, "whether that's action, a change of attitude, or even simply enjoyment on the part of the reader" or horse (Dean 53). And as a bonus, when teachers successfully eliminate "real fear" in the classroom and instead invite student writers to 
experience the "nervous fear" that comes with writing with a real, live purpose, both students and teachers have a "much more pleasant experience" in the classroom, "- and that means more learning... too" (Dean 58).

\section{Circles to Normalize Writers' Fears of the Writing Process}

In addition to creating an opportunity for nonthreatening reader response, writing circles can create a space for productive reflection that can embed a set of values about the worth and purposes of writing. Instead of communicating that the final text is "writing," noun, our whole class conversations about writing with other writers can embody Yagelski's belief that writing is a "practice of being," verb, an action, a way to connect to ourselves, our ideas, others, our world (Mathieu 175). Currently, in writing factories, the "revulsion" or disgust students feel throughout the writing process are left unacknowledged, "mak[ing] students feel dumb" or isolated or afraid when they have a negative emotional response to writing (Writing With Power 173-4). In a circle, where trust in the community has been established, students can learn to "enjoy the daily grind" of writing with other real writers and embrace the "privilege of struggle" rather than resisting it, just like Emerson says is essential in becoming an effective rider (Emerson 100). Specifically, Blackburn's “meta-moments" can be used to host conversations about the challenges of the writing process. At a point when the teacher notices students holding (normal) negativity towards their writing, the students can discuss the following: "(1) How am I feeling in this moment" of the writing process "- what do I notice about the emotions I am experiencing as I engage in this discussion? And where can I trace the source of these emotions to? (2) ... What larger - or even, more personal - issues are underpinning" my experience as a writer, "and how might those issues be related to how I am emotionally experiencing this" writing 
experience? (Blackburn 61). Teaching students to process negative emotions about writing in a reflective, productive community can normalize the fear and disgust writers experience and give students an opportunity to "reorient themselves back to a place where they fe[el] more capable" of completing the writing task (Blackburn 61). Deborah Dean says this type of visible reflection is necessary to help students transfer the skills they're learning to future writing scenes and emphasizes a positive "way of thinking" about the act of writing (10). Here are the questions she poses to students, which could also be discussed in the context of a circle: "What did we just do? How did it help you? How might you use it in other writing situations?” (10).

The factory-model of education would have us believe that the "time and energy" that it takes to teach students to view themselves as reflective and capable writers who are engaged in the ongoing act of writing, despite the negative emotions they may experience along the way, is wasted, but in reality, these are essential "mental" skills for writers and riders to develop (Dean 10; Emerson 73). Emerson says that riders must balance "mental" and "physical" practice in order to see real improvement; "the trick is first to believe it is possible to change [a skill], and then to figure out how to 'practice' it" (Emerson 73). By reflecting aloud in our circle with our students, we can teach them how to work through the "swamp" and "stupid game [we] play with [ourselves]" during the writing process and get on with learning to write better (Writing With 173)

Please note this is not a need that riders or writers ever outgrow: my decade of riding experience did not make me immune to the fear and disgust of learning to ride Sparty, and I needed the same reflective skills to confront my rider-ly "nausea" as Jenna did at a far earlier stage of her riding career. Similarly, I am currently "nauseated" by the writing of this chapter even after nearly a decade of post-secondary education in the same way that my high school 
students are frustrated by writing paper debates (Writing With 173). All learners, writers, and riders need reflective skills to "reorient" themselves, process the meaning and value of our emotional responses, and "come back" to the writing process when they are "better able to more forward productively" (Blackburn 62-3; Writing With 175). Rather than framing disgust towards writing as a sign that students are not any good at writing and ought to avoid it at all costs, we must frame our emotional responses "as encouraging, common, and generative signs" that the act of writing is well on its way (Blackburn 66). In other words, when writers are emotional, positively or negatively, they are engaged in a normal, intense, powerful, productive, present moment of their lives that teachers should embody, invite, and foster so that students have the mental tools necessary to write far beyond the bounds of our classrooms (Thiel 37-8).

\section{Humanizing Grading Processes Through Conversations about Writing}

Even in the healthiest learning community, the act of grading and being graded can easily “destroy the relationship" between the teacher and the student, perhaps because many students feel "traumatized" by the negative feedback they've received from past teachers who have inhabited the role of critical "judges" or merciless "prosecutors" when evaluating student writing (Reimagining 8-9; Holiday 36, 41). Similarly, the act of justifying points can put the teacher on the defensive due to past perceptions of them as "villain" when they released grades and passed back rubrics (Rethinking 135). However, our students are much more than "Pac-Mans," "accumulate[ing] points as they gobble their way through one grade-level screen of wafer-sized learning targets after another" and our teachers are not "essay scoring machine[s]" (Reimagining $110,21)$. Both the student writer and the teacher is a human being, "someone's child, someone's friend, someone's neighbor, and perhaps someone's parent, now or in the future," and the act of 
evaluation is "a simple moment between two people" about the deeply human and personal art of writing (Reimagining 137). This description of grading is vastly different than the impersonal stack of research papers that are sitting on my desk, waiting for me to pull out a common rubric, circle some boxes, add up the points, staple the evaluation to the paper, and hand it back when I take attendance the next day. I'll likely throw in a well-meaning "let me know if you have any questions" when I hand it back, knowing that only one or two students will actually ask. The rest will likely and understandably look at their score and toss the paper into the recycling bin on the way out of my classroom.

In order to restore the humanity in evaluation, Maja Wilson says we must first let go of our "societal obsession with superficial markers of growth," like detailed rubrics and complicated scoring systems that provide a false sense of objectivity and student growth and start having "conversations" with students about their writing and the way we, the assessor, actively experience the writing as a real reader (Reimagining 50, 137, 69). "It seems stupidly simple," but if we wish to maintain and strengthen the "micro-community" between the teacher and student during the evaluation process and eliminate the mutual fear of grades, teachers must sit down and "look" the student writer "in the eye" when evaluating, what Wilson names "one of [our] most sacred professional duties" (Wachtel 143; Reimagining 137, 2; Farley 242). In this way, writing teachers can embody one advantage of riding coaches: devoting individual attention to one writer at a time throughout the course of the writing conference, like riding coaches do during a private lesson. By doing so, the students are able to know the teacher and the teacher is able to know the students; they can begin to see and hear and trust each other as individuals, the first step in learning to write (Murray 16). 
Wilson says these face-to-face "writing conferences" with students should "happen early and often" throughout the planning, drafting, revising, and grading process "outside of class, or in class while students are working" (Reimagining 76). The purpose of meeting individually to discuss the writing "isn't for the teacher to give advice... but to invite the student... to speak and to listen [to herself]. The writer may forget any particular suggestion from the teacher when the class is over. But she'll always take her... self with her" (Reimagining 76, 89). This idea aligns with Bob Broad's and Deborah Dean's view on the purpose of responding to student writing. They each argue that our feedback should assist students to "self-initiate" and "selfselect" writing tools that are "strategic" and rhetorically effective in the future (Broad 15). Any feedback that the teacher does provide during the writing conference should not be judgmental or "shaped by standards or learning targets" but instead should focus on providing hope to the student as they learn about "how writing works and how writers develop" (Reimagining 92; Holaday 41).

This timely, recursive, "educative" feedback is much that of a riding coach who can "give... tips" in real time during the rider's experience with their horse to "help them understand" their active riding process and improve their independent riding skills (Wiggins 1; Cochran 252). Later, riders will be ready for harsh evaluation from a highly-trained dressage judge who will pick apart each movement of their performance. ${ }^{4}$ But during riding lessons and writing conferences, students need their "coach," "someone who cares about us, challenges us, and comforts us" to help them "meet the standards of the outside world" and "to tell them

\footnotetext{
${ }^{4}$ See chapter three for a more detailed account of the role of the judge in riding's national assessments.
} 
specifically what it is they do well" while they are developing their own sense of identity as a rider or writer in a "safe place" (Holaday 39, 41; Better Than 61; Wachtel 143).

I was fascinated by the theoretical effects of this humanized grading practice, so I put it to work in my British Literature course of juniors and seniors this semester. Throughout our first unit, I adhered to the values articulated above about allowing students to speak first and only providing descriptive, productive feedback during conferences; I channeled my inner riding coach voice. Throughout their writing process, students met with me for three grading conferences, and at the end, I asked students for anonymous feedback via a Google Form. I asked, "Tell me about your experience in the grading conferences? How did they make you feel?" Below are some of the responses that stood out to me.

- I liked the conferences because I feel like it gave us a chance to see you as a person and get more comfortable with you instead of seeing you as a machine that only works, if that makes sense.

- I feel that the grading conferences gave me a lot of feedback on how I was truly doing compared to what I thought. At some points, they made me feel frustrated with myself, but at some points they were rewarded.

- They made me feel slightly uncomfortable. It vaguely reminded me of a job interview. However they were quick and my genuine and honest opinion for the grade I deserved was taken into serious consideration.

- I really enjoyed the grading conferences. It allowed me to reflect on how I did, and how to improve myself. I wasn't worried at all and looked forward to them because they were more calming. The time for reflection was nice to have.

- It made me feel relieved to confess my feelings in the grading conference. 
- You did a good job of allowing us to speak about how we felt and then gave us your opinion on what we said. It made me feel confident.

- The conferences were a great way to allow you to do some personal reflection with someone who was going to keep you accountable.

- They made me feel right in the middle. I wanted a higher grade than I got but did get a higher grade than my original grade. Ms. Koehler was good at reasoning why I got that grade and I could not really argue it.

Students describing how the grading conferences made them feel "relieved," "confident," "calming," "rewarded," “comfortable," "accountable" makes me feel successful as an assessor. In my four years of teaching experience, grading has ruined many budding relationships with students, and in this instance, it actually brought us closer together. I am equally excited that conferences made some students feel "uncomfortable" or "in the middle" or "frustrated"; that means students were experiencing the type of cognitive dissonance that leads to real learning (Blackburn 60). Holding grading conferences gave us a space to normalize and work through those negative emotions about their writing and allowed students "to see [me] as a person... instead of seeing [me] as a machine that only works." Shocking, I know, but yes! I am a person and evaluating writing is incredibly nuanced, human work. This idea confronts our students' blatant obsession with "objectivity" and allows them to see me as an expert teacher, who they have a trusting relationship with, reliably, carefully, magically assessing their work aloud with them.

In sum, when we support students in their individual development during writing conferences rather than scaring them, and ourselves, with emotionless, unreliable evaluation tools, not only will their writing improve in the short term, but we can "rediscover the sacredness 
of the student-teacher relationship," allowing our students to "grow as a person who uses the written word to see, feel, hear, ask, know, create, make sense, express, and communicate" in our democratic society (Thiel 44; Reimagining 110). ${ }^{5}$

\section{Conclusion}

Like riding coaches, we must urgently and intentionally and vigilantly recognize and confront the fears that students and teachers face in our writing classrooms as part of our daily instructional and assessment routine. As explored in this chapter, we can do so in the following ways:

- Create "horses" for students to experience "nervous fear" and write better in honest, rhetorical situations, including within a classroom circle

- Normalize and share fears writers face throughout the writing process and regularly experience reader response within the classroom circle

- Humanize the evaluation process so teachers and students can safely grade and be graded using private writing conferences

The factory-model of education would have us believe that the instructional minutes spent instilling "safety and confidence first, at all times" (Wallace 95) is all a waste of our time because it could slow down the production rate in our classroom. But if we're going with this metaphor, who wants to drive a car that was thrown together in a jiff but falls apart the second it hits a speed bump on a real highway? No one!

\footnotetext{
${ }^{5}$ This is the type of work we need to do consistently in our classrooms in order to earn our students' and other stakeholders' support for teachers assessing large-scale writing assessments, as I outline in chapter three.
} 
Our students are about to embark in a lifetime of writing potholes, nasty curves, and thrilling speed chases, and their self-esteem as writers and the "arrows" they have in their "quiver" must be able to withstand and adapt to the rhetorical situations they find themselves immersed in. That type of sustainable, reliable writer takes, and is worth, the time it takes to "nurture" those skills, just like in riding (Wallace 80). Plus, "trust, the foundation of all interactions, dictates the speed at which progress in our classrooms and schools can be made.... Transformation," and writing and teaching and learning and riding, "works at the speed of trust" (Murray 31). Under this assumption, our writing classrooms will actually be able to move faster when we eliminate fear, build confidence, and engage fully in the human, intimate, magical work of teaching and assessing writing.

Doing so does not mean we're abandoning rigor or commitment to our content; it means just the opposite. Riding coaches enable their students to ride effectively at great heights because they are patient in their rigorous and supportive instruction. Wallace says, "If in doubt, don't. There's always another day" (Wallace 87) and that we must treat "children [like] individuals like horses" while we push them to greater feats (Wallace 87, 29). Similarly, Elbow says, “...in order to teach [writing] well we must find some way to be loyal to both students and to knowledge or society" (Embracing 158). It's a balance, or as Elbow would say, a contrary. Our schools have been too focused on the "what" for too long, and we, as "knowledgeable teachers, invested writers, and compassionate human beings who teach for a more inclusive democracy," must recognize the fear in our students that has made them disengaged, apathetic, and hurt and the fear in ourselves that has made us defensive, cynical, and clenched, and then face it.

Similarly, our large scale assessment of student writing, currently the SAT, also promotes the factory-model's obsession with the "what," a piece of rushed writing that students are forced 
to produce in a timed setting with no rhetorical purpose or opportunity to reflect or revise.

Chapter three explores the damaging effects of our current large scale assessment practices, including the miseducative feedback that is provided to students and the lack of qualifications of Pearson's “scorers," and uses eventing's assessment practices as a starting place to imagine what a more humane, educative large-scale portfolio assessment could look like in writing. 


\section{CHAPTER III: ENOUGH HORSING AROUND: RAISE THE BAR FOR WRITING}

\section{ASSESSMENT}

The culminating result of our teaching is showcased during the high-stakes assessment in each field: nationally recognized riding events and the SAT writing assessment. According to the SAT Suite of Assessments website, the writing test is meant to provide a standardized measure of "what students learn in high school" and "what they need to succeed in college," and in riding, "the thousands of hours of practice comes down to this moment" at the event ("Inside the Test," Dutton x). Except alarmingly, multiple arguments have been made that our large-scale writing assessments "are simply not doing what they were designed to do" and that there are alternative assessment methods that would better allow teachers of writing and student writers to do their best work (Spangler, et al. 11-2).

For example, a team of Illinois teachers made an articulate argument for reconceiving our large-scale writing assessment in 2004, over fifteen years ago. This group proposed the Illinois State Portfolio Assessment of Writing (ISPAW), a collection of writing that would be selected by the student writer and revised extensively under the watchful eye of the student's expert teacher (Spangler et al.). This portfolio could be evaluated by multiple, informed, trained judges: teachers who have been immersed in the building of students' portfolios and who are personally invested in providing quality feedback. It would mutually benefit our taxpayers by rewarding our local teacher experts rather than "diverting taxpayer money from where it could do the most good," to unqualified strangers who score from afar and profit Pearson (Reimagining 20). Vermont successfully implemented this type of portfolio assessment during the 1991-1992 school year when teams of teachers evaluated students' writing based on five criteria: “purpose, organization, detail, voice/tone, and grammar/usage/mechanics” (Hewitt 4). Similarly, several 
university writing programs (including Miami University, State University of New York -- Stony Brook, University of Cincinnati, Washington State University) "now use portfolios to place students in composition courses or to certify students' writing competency" and there are “sweeping benefits to students' learning” (Broad 8). In his article, "Toward a New Theory of Writing Assessment," Brian Huot proposed an additional five assessment programs that promote "site-based, locally controlled, context sensitive, rhetorically based, and accessible" alternatives to the SAT (Broad 10).

These performance-based assessments are not new to our society. Geof Hewitt offers The Boy and Girl Scouts' and the military's strict performance assessments as well-respected examples of assessments that "require active observations by teacher and student" $(169,167)$. Instead of judging student performance with "a single letter grade applied at the end of each marking period," these assessments provide "an ongoing conversation during which mutually accepted standards of performance are assessed" (167) by the teacher.

Strangely, these options have not received any serious acknowledgement or attention, even though students, teachers, principals, school boards, parents, and superintendents "hate," and I argue fear, our current large-scale writing assessments (Hewitt 167). My hope is that comparing the assessment of national riding competitions to the SAT writing test will encourage teachers to be "change agents" (Gallagher and Turley 72) and give serious attention to alternative assessment methods that humanize the process for students and their teachers. As part of the comparison, I will examine the format of the assessments, the preparation practices before the "big moment," the issues of access that accompany the assessment, the role of the teacher at the competition, and the value of the feedback after test-day. 


\section{The Flawed Format of the SAT and Choice-Driven Portfolios in Eventing}

Although both writers and riders are assessed on national scales, it is important to acknowledge that our student writers are not given agency when it comes to the SAT. Every junior in high school is mandated to take the exam in the same format whereas riders are faced with loads of choice when it comes to high-stakes assessment. To start, riders choose when (if ever) they are ready to be assessed. They also choose the venue, equipment, coach, team, and genre of riding. For example, a rider could choose to engage in reigning, where horses are asked to spin and slide to a stop; ranch riding, where horses have to navigate realistic obstacles like bridges and gates; roping, where live calves are chased and temporarily pinned to the ground; speed events, where horses run a single pattern as quickly as possible; fox hunting, where teams gallop over natural brush and fence obstacles; etc. Each genre of riding attracts people with different personalities, interests, and ability levels.

For me, three day-eventing is the most engaging genre of riding. Eventing's assessment was originally intended to assess the variety of skills necessary for an Army horse and officer pair to be successful: "grace, refined beauty and elegance" in dressage; their adaptability, stamina, and courage in cross-country; and suppleness, energy, and obedience in show-jumping (“About Eventing”).

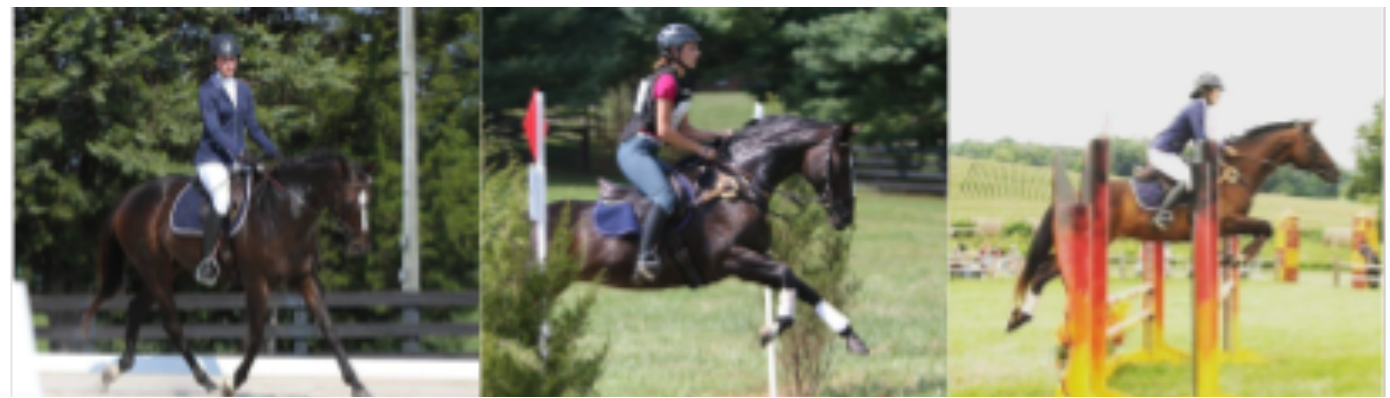

Figure 5: Me and "All That Glitters" competing at novice level USEA events 
Eventers are known to be courageous because of the danger of the cross country phase.

If the horse and/or rider make/s a mistake at a natural obstacle, like a ditch (pictured above) or a wooden fence, the consequences can be fatal for either party. I am personally attracted to those stakes and value the bravery the horse and rider team must show. The beauty of riding is that not all riders are forced to choose these stakes; some may feel safe and engaged by the exacting precision of roping calves or perhaps the freedom of trail-riding alone. This element of choice reduces anxiety and fear for riders because they are not forced to ride in a way that frightens them.

Students are not offered the same humanity of choice during the SAT national writing assessment. Every student is given a multiple choice exam and essay-test. In the multiple-choice section, students are allotted 35 minutes in which they are to read four passages in different genres and answer 44 multiple choice questions that ask for the best evidence to support a claim, the most precise word given a context, the correct grammatical choice, or best organizational strategy. The essay-test asks all students to respond to a standardized writing prompt in 50 minutes and is scored using a predetermined analytic rubric that reports students' abilities to comprehend a passage, analyze the author's argument, and produce a focused and organized essay.

The element of time, or lack thereof, is enough to be frightening for students, and this "bland, formulaic writing" in a "rigid" setting does not give them an opportunity to showcase their unique skills in an environment that suits them (Spangler et al. 15). Instead it privileges writers with personalities that allow them to mechanically crank out "blether," a Scottish term that means "unfocused, rambling, and more or less thoughtless" writing in a single sitting (Hillocks 77). This would be the equivalent of making every person that rides horses compete in 
speed events; even though I love horses and riding, running a single pattern in as little time as possible simultaneously induces my anxiety and bores me. Simply put, I have no interest in learning to ride in a speed event, but when given the opportunity to learn how to jump a massive cross-country fence, I am excited to lean in to the challenge. Our student writers are no different, and as humans with unique needs and interested, they deserve choice when it comes to their high-stakes assessment task. ISPAW would "allow students significant choice regarding the contents of their portfolios and will require multiple and varied writing performances" (Spangler et al. 19). If we allow students to choose the genre of writing they engage in based on their interests, personalities, and strengths, the assessment will allow students to safely, confidently write, therefore providing us with "a far more complete and satisfying portrait of their writing skills than the snapshot produced by one-shot, timed writing" (Spangler et al. 19).

In addition to scaring our students by forcing them into a "speed event," the SAT's assessment methods are frankly outdated. Multiple-choice tests have been used since the 1920s when universities and the military were overwhelmed with applicants for the first time and needed a way to "rank, sort, and analyze" candidates fairly and quickly (Rethinking 16-8). These tests still appeal to our modern need for expediency, since computers are used to score them. These "objective," indirect tests of students' grammar and usage continued to be used as the sole way to assess students' writing until 1970 when stakeholders began to question if asking students to correct another writer's work using predetermined answers was really a direct or valid way to assess students' ability to produce text. Enter the essay-test as "the second wave" of writing assessment, a giant leap forward in evaluating students' actual composing skills (Yancey 133-4). This seemingly benign assessment began to be challenged in 1986 when Peter Elbow and Pat Belanoff argued that essay tests "undermine good teaching" because 
"having a serious topic sprung on you (with no chance for sharing or reflection or discussion) and writing one draft (with no chance for sharing or feedback or revising)," without any consideration of the text's rhetorical purpose, is an invalid snapshot of a students' writing ability (97).

Nearly 35 years ago, Elbow and Belanoff advocated for high-stakes portfolio assessment, which could include "two or three samples of her writing - in two or three genres at two or three sittings" (97), rather than the disproportionately narrow sample that the SAT essaytest collects. Much like writing, quality riding cannot be reduced to a single skill or opportunity, and eventing's portfolio assessment rewards well-rounded riders who are able to successfully navigate all three phases with their equine partner. In this way, eventing can provide a model for teachers of writing to use to advocate for high-stakes assessment reform that allows us to move towards "third wave" portfolio assessments that allow students to compose "challenging, varied, and sophisticated" writing (Yancey; Spangler et al 18).

\section{Preparation to Condition Fit Writers and Riders}

At the time of writing this chapter, I am also serendipitously involved in collaborative conversations with my department about how we will prepare juniors for their upcoming SAT on April 14th, a mere six weeks from now. The tone of these department email exchanges and occasional in-person meetings is negative; none of us want to design SAT preparation materials on top of our already stuffed, regularly-scheduled school-day. Our compromise is that we will use Khan Academy, a free online preparatory site during the 25-minute homeroom periods for three weeks, a total of 375 instructional minutes. The students that will come to me for SAT prep are not students I teach in any classes, so I am not familiar with their abilities or needs. 
KhanAcademy is supposedly "for every student, every classroom," which is ironic since our administration resorts to supplying candy to incentivize our students to use at least fifteen of the 25 homeroom-minutes to practice using the standardized website content. Because my department feels so disconnected from the SAT assessment and preparation, we happily direct the students to use the resources on this website and reward them with candy when they complete a "quota" of activities that we will never grade or refer to again.

The eventing community warns against this type of intensive, short-lived preparation before a show because it can cause "undue stress and exhaustion" and fear that can lead to injury or burnout for the horse or rider (Dutton 67). Olympic rider Phillip Dutton says this "fitness is not attainable overnight: It takes time, planning, and hardwork" (67), and as a result, he outlines multiple fitness plans that span the course of months or years. Hewitt likewise says student writers need "to develop a writer's muscle" through at least ten minutes of practice each day to "improve their skills" and "stay in shape" (19). In eventing, we would never ask an unfit horse or rider to enter a competition for fear of the consequences. Similarly, we must create circumstances that allow our student writers to stay conditioned to safely accomplish their writing tasks. That means aligning our high-stakes assessment in writing to "correspond with what teachers do in the classroom throughout the year" (Spangler et al. 21), rather than asking teachers of writing to step away from the regularly-scheduled program in our English classrooms to rely on "overnight" preparation using KhanAcademy.

The current preparation practices for the SAT also demeans teachers' everyday work in their classrooms. Across the country, teachers implement "best practices in the teaching of writing" that allow a classroom to be "a dynamic place of growth, discussion, development, research, synthesis, and change for both teachers and students," a place where students are 
challenged "to think in new ways, conceive a variety of audiences, identify real issues that matter to them, and cultivate their distinctive authorial voices" (Spangler et al. 16). Then, upon the arrival of SAT season, "anxious" teachers become babysitters for students while a computer program supposedly teaches them how to write for the most influential moment of their secondary career. Teachers are forced to answer students' questions about why all of our talk about "the writing process" comes down to "an external prompt in a timed situation" (Hewitt 7). Doing so undermines our everyday work, wastes district resources, scares our students and teachers, and warps our students' ideas about writing's fundamental purpose in our democratic society.

\section{Issues of Access with Preparation Practices in Both Spheres}

The SAT preparation practices I describe above are free to students who choose to use them within the public high school where I teach, but many students purchase additional preparation materials outside of school. For example, local Bradley University offers a SAT review class that meets for two hours a week for five weeks immediately before the exam,

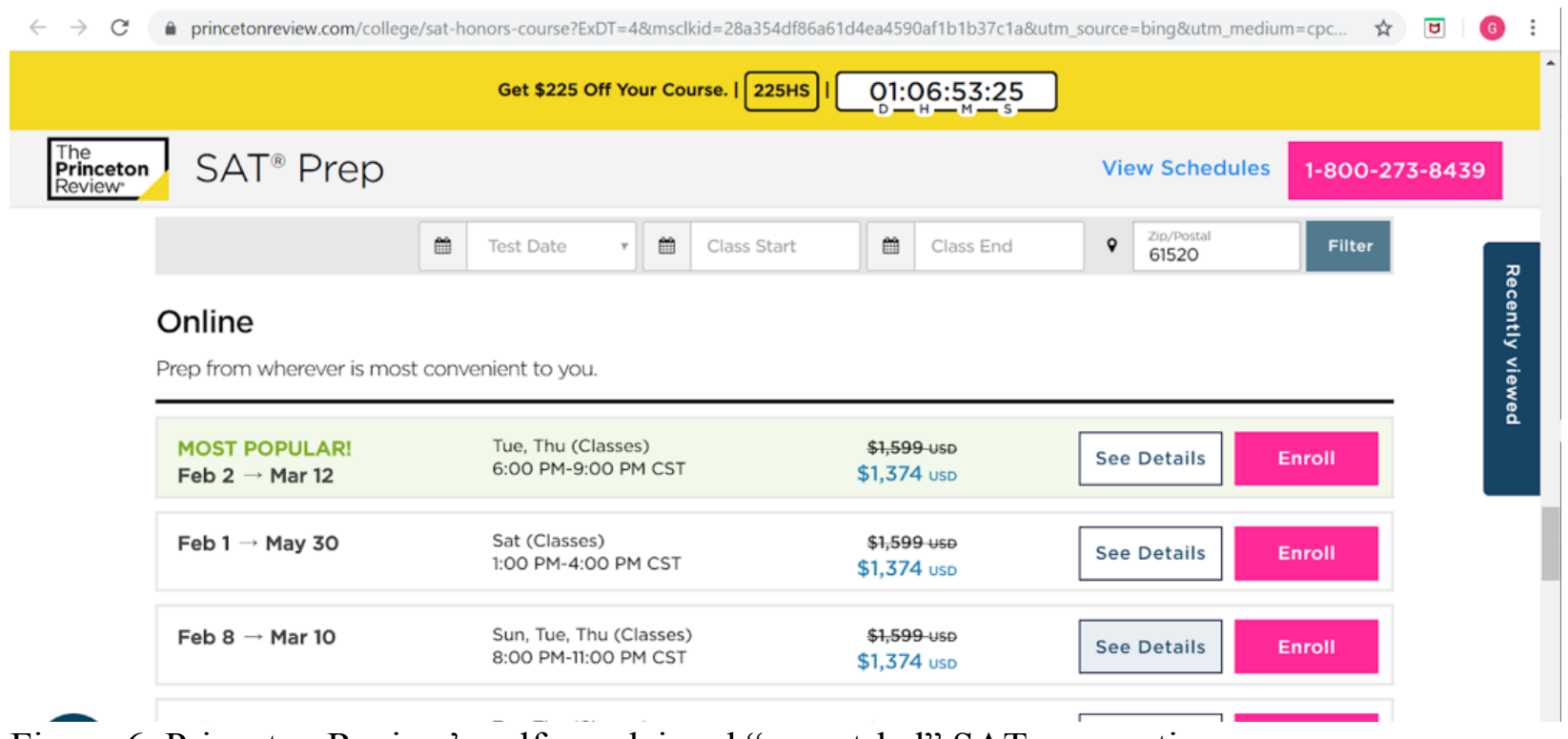

Figure 6: Princeton Review's self-proclaimed “expert-led" SAT preparation 
another "overnight" preparation practice. This course costs students $\$ 95$ to register and the required textbook, “Barron’s SAT Premium Study Guide,” costs \$21.99 on Amazon. If students are not able to find transportation to a local SAT review outside of school, students can "prep from wherever is most convenient” through Princeton Review’s self-proclaimed “expert-led” SAT prep for a mere $\$ 1374$. If that option is too much for students, they can also hire a private tutor. I charge $\$ 45$ for a private 45 -minute tutoring session with me, a certified teacher.

While I would love to say that riding makes preparing for high-stakes assessments more affordable, preparing for an event also traffics wealthy people. If I want to take a private 45minute lesson with a top-level rider, it costs me $\$ 75$. Similarly when I coach a student rider for 30 minutes (in order to be able to afford a $\$ 75$ lesson with a better rider than me), I charge $\$ 35$. In other words, I have to charge a high rate for instruction because I am part of a larger system that makes seeking help from "expert” riders exponentially expensive and unaffordable for low and most middle-class families. If we assume that using these expensive preparation methods benefits writers and riders, then not all students are being given the same tools to succeed in our current high-stakes assessments. In other words, wealthy students have an advantage by having access to additional preparation that others cannot afford.

Another accessibility issue is the way that both high-stakes assessments encourage students to "redo" the assessment multiple times in order to earn the highest score possible, a costly revision process. College Board reports that " 2 out of 3 students in the class of 2018 , a total of $63 \%$, increased their SAT score by taking the test more than once," and they recommend that each student takes the test at least twice ("Should I Retake"). Similarly, throughout the course of a riding season, my scores improve at each event. Both spheres assume that every student has the means to "redo" the high-stakes assessment, which does not create equitable 
access for all. To take the SAT with the writing test outside of the single time that local taxpayers fund through the public high school, a student must pay $\$ 64.50$ before any fees are tacked onto the final tab. Similarly, a nationally-recognized riding event can cost up to $\$ 500$ in entry fees alone, and if coaching is needed during the show, that costs an additional $\$ 150$ from a top-level rider. Specific attire is also required at competitions, like specific calculators are required for the SAT, and hauling fees may apply if the rider does not own his or her own truck and trailer to transport the horse to the venue. This issue of reliable, affordable transportation could also prevent a student from being able to get themselves to a SAT testing location.

Shifting towards a portfolio assessment would begin to answer these accessibility issues by allowing all students to revise the assessment recursively with their classroom teacher before submission. This option is fairer to our students because it reduces the likelihood that a student would need to spend additional resources retaking the test or finding transportation to an outside testing location. Instead, students could access the feedback they need to produce their best writing over a considerable span of the school year from a teacher who knows them best (Spangler et al. 19). Taxpayers would also benefit because they have already paid expert teachers to teach and evaluate students' writing within our public schools. In other words, there is no need to invest in a faraway Pearson when expert teachers are already doing the the essential job of assessing our students' writing in their classrooms everyday.

\section{Writing Results: "Miseducative" SAT Scores from Underqualified Scorers}

What happens after the day of the SAT writing assessment is no less flawed than the preparation process. After our students have taken their essay test, "qualified" scorers of the SAT take over. To recruit SAT scorers, their website advertises the benefit of working from home 
with flexible hours ("Become an SAT Scorer"), much like telemarketers do. To find out more about the qualifications, I began an online application to become a scorer through Pearson's employment portal. On the first screen, I was assured the application would take no longer than 15 minutes. A few clicks later, I found out more about the position:

\section{Job Description}

Scorers will work from their homes, evaluating student responses to subject-related open-ended questions according to a customer supplied scoring guide. Candidates must qualify after completion of training in order to begin scoring.

Pearson offers compensation packages that reward exceptional quality and productivity. Scoring is generally compensated at a wage of $\$ 12 /$ hour with additional incentives paid based on daily and weekly performance (up to $\$ 150$ per week)

\section{Requirements}

- Conferred a minimum of a Bachelor's Degree from an accredited college

- Eligible to work in the United States

- All scoring and other work activities must be completed in the United States

- Basic computer skills (keyboard, mouse)

- Ability to maintain a confidential work environment

- Access to a home or office computer that meets the requirements of the scoring system, internet service, and telephone connection. For

security reasons, readers may not use shared office computers or work from institutional or public computer labs.

- Availability to work a minimum of 30 hours per week

- Teaching experience is preferred

\section{Major Responsibilities}

- Evaluates student responses to open-ended questions in a reliable manner and scores according to customer supplied scoring guide.

- Successfully internalizes training and customer scoring guide.

- May be required to pass qualifying test before scoring.

- Must be able to put aside personal biases and apply scoring guide according to customer requirements.

- Must be committed to working the required number of hours each week for duration of the project.

- Meets rate and quality management standards established for project.

\section{Currently supported Operating systems (OS) for Pearson's scoring system}

- Windows: 7 and 8 (in Desktop Mode only)

- Mac: Mac OS X 10.7- 10.11

- In addition, monitor capable of a screen resolution above $1024 \times 768$ is needed.

- Some projects will require the ability to play audio.

- We do not support mobile operating systems (Android, Apple iOS, Chromebooks, and Windows RT).

Figure 7: SAT scorer job description from Pearson

As a brief paraphrase, SAT scorers must be able to operate a computer and access the internet on a secure network, both basic skills. They must also have 30 hours a week at $\$ 12$ per hour to devote to Pearson, meaning they have chosen not to secure another full-time professional job that would almost certainly pay more. They can hold any Bachelor's Degree, not necessarily in English or Writing, and are not required to have any teaching experience, meaning most will have no expertise in quality assessment, norms for student writing, or educative feedback. 
Further, they are expected to produce "reliable" scores (meaning the same scores as other qualified scorers, not necessarily accurate ones) in the time that is "established" by the "rate and quality management standards... for the project" (not in the time necessary to carefully read and evaluate the student's writing). They must also "internalize training and [the] customer supplied scoring guide," regardless of personal opinions or biases, which is essential because "readers who pay attention to their experiences slow down the production of scores" (Reimagining 24). The seriousness of the reliability aspect was emphasized again; before collecting my work history, Pearson warned me about "scoring eligibility":

\section{Pearson Application for Employment}

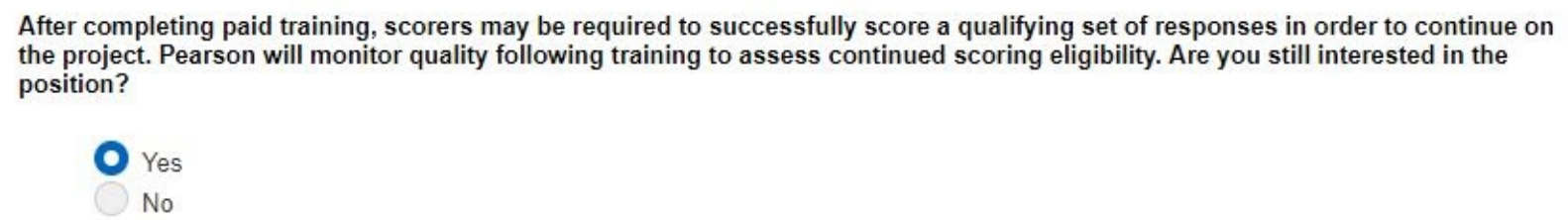

\section{Previous Page Next Page}

Professional Scorer - Working from Home

Figure 8: Pearson's “scoring eligibility" clause

Overall, Pearson has created a "writing assessment factory" by "turn[ing] human readers into tools" that are stripped of their ability to interact with students' writing as an authentic reader (Reimagining 20). Instead, the process of evaluating students" work has been "fragmented" into traits that are meant to "narrow readers' focus" and correlate with a scale that produces a score. In practice, "the mechanical heart of the writing assessment machine" (Reimagining 20) beats by scoring three traits on an analytic rubric that uses vague descriptors to differentiate between the quality of the traits: for example, analysis can be "insightful," "effective," "limited," or 
"ineffective" ("SAT Essay Scoring"). There is no personal feedback provided to our students on their writing; instead they receive a series of three numbers between 4 and 1 that correspond to the scale. For example, a student might receive a "3-2-2" on their writing.

SAT dedicates multiple pages of their website to explaining the process of interpreting, what they call, the "mystery" of the scores and how to send them to colleges to impact their admissions ("Scores"). However, they do not mention how the scores, that are so influential to our students' futures, can be used by the students to further their learning. Therefore, we can assume the scores, the only feedback students are meant to receive on the most influential text they produce in their secondary career, is not meant to be "educative," part of the continuous learning experience; it is meant only to "audit" their performance (Wiggins 1). This is not beneficial to our students' growth as writers; in fact, John Dewey would call this feedback threateningly "miseducative": it makes our students "callous" to future writing opportunities by reducing their ability to a single prompt, opportunity, and score (13).

\section{Riding Results: "Educative" Scores from Highly-Qualified Judges}

Meanwhile in the riding community, each phase in the eventing portfolio is assessed differently. While cross-country and show-jumping earn completion scores from nonprofessionals, dressage assessment allows highly-qualified judges to respond to riders with educative feedback, using an analytic rubric. ${ }^{6}$ In addition to providing a numerical score for each movement, the judge also has the opportunity to offer narrative feedback via a scribe, who records what the judge is saying while watching each part of the test. These comments are more observational than evaluative and are reminiscent of the Elbovian "movies of the mind" that

\footnotetext{
${ }^{6}$ See Appendix A for a sample Dressage rubric that was used to assess a test ridden by Koehler.
} 
Wilson proposes as a response technique (Reimagining 98-101). These movies refrain from evaluating and instead record what the reader, or in this case, viewer, is seeing as they read, or watch the dressage test. For example, past judges have written the following observational comments on my rubric: "fairly active," "pulling to walk, unsteady," "some weaving on C-line," "needs more march," "clear rhythm," etc. After the rider completes the test, the judge is allowed time to wrap up any final evaluative, personal, responsive, comments that will help the rider "learn something about [her] riding or [her] horse" (Burkhardt 247). Below are some final comments I have received from judges:

- "Lots of potential - work on steadier more accepting connection. Good luck."

- "Tension takes some freedom away from gaits but horse looks capable and rider does a good job."

- "To right, uneven in hands - try to straighten! Fluid canter w/ good jump and thru-ness." Riders are encouraged to look beyond the numerical score they receive (Burkhardt 231) and focus on how these comments can assist them in "the progressive plan that you have for yourself and your horse," "back home," rather than just "today," a single snapshot of the horse and rider's ability (Burkhardt 248, Bryant 248). This philosophy aligns with Wiggin's and Dewey's commitment to providing educative feedback that promotes future learning and is what separates eventing assessment from the threatening, miseducative "audit" of the SAT score, where the value stops at the number.

Another key difference between eventing and writing assessment is the qualifications of the evaluators. Unlike the underqualified SAT scorers, at a national United States Eventing Association Event, feedback is given by Dressage judges who are rigorously certified through the national United States Equestrian Federation ("Eventing Officials"). In order to judge at a 
national event, applicants must meet the following requirements ("Dressage Judges Training Program"):

- Show professional interest by becoming a Senior member of USEF

- Demonstrate commitment and capability by completing a preliminary training course "L” With Distinction through the United States Dressage Federation

- Showcase their own riding skills by earning five exemplary dressage scores at the highest national level of Dressage from four different certified judges

- Complete an online series of lectures and quizzes and a classroom session of 6-8 hours

- Practice judging Dressage tests at USEF licensed dressage competitions

- Pass a written, oral, and practical final examination

- Apprentice judge a total of 22 classes at four different USEF competitions with at least two different certified judges, who must submit official evaluations of the apprentice's performance.

- Submit 12-15 recommendation letters from licensed Dressage judges, technical delegates, or other members of the Federation Dressage Committee.

These rigorous qualifications ensure that dressage judges are incredibly competent riders, are intimately familiar with the judging process in practice, and are highly recommended by at least a dozen other qualified professionals in the field. Riders can then trust that the judge's evaluation of their riding is reliable and should be taken seriously. It puts the fifteen-minute application, online reliability training, and lax degree requirements of the SAT scorers to shame and further highlights the gross negligence of our current standardized writing assessors, who are not qualified to label our students' writing, especially given the enormous stakes for our schools, teachers, and students. 


\section{During the Assessment: "Ringside" Coaches}

In addition to trusting equine professionals to evaluate the rider's performance, "a great trainer" is fully invested in the learning process before the event and is physically "there" (Dutton x), "ringside" at the event to "give... tips" during the rider's warmup, to see their performance, "help them understand what went amiss," and "help them correct the problem" in future lessons (Cochran 252-4). This trainer is already intimately familiar with the rider's strengths and weaknesses and can deliver last minute instructions during warmup at the show. For example, my coach tailors my instruction at the show to my mood that day and level of preparation. This role is much like a classroom teacher who has "coached" his or her writers daily throughout the school year and knows how to lesson anxiety and elicit the best work out of each student in a variety of circumstances.

However, during the SAT exam, students are isolated from their "coach" and teachers do not have access to their students' work or educative feedback after the exam. We frighten our students by sending them in alone, to complete a writing test that exists in isolation from the rest of their writing career. Instead, teacher experts should accurately, supportively, educatively assess multiple drafts of students' work, "ringside," as part of a safe high-stakes writing process that simultaneously builds students' confidence and skills. If expert teachers are available as "resources" to students throughout the process of creating a portfolio of their best writing, we can also raise our expectations for the quality of students writing and expect students to reflect on their mistakes in order to continue in their lifelong development as writers in a democratic society (Spangler et al. 19). 


\section{Will "Objectivity" Continue to Hold Us Back?}

Three-Day-Eventing collects a multi-genre portfolio that is assessed by highly qualified, trusted professionals who provide educative feedback to well-conditioned riders, even though for most competitors, eventing is a low-stakes hobby. Why, then, do we allow our students' entire writing ability to be labeled by a uni-dimensional score that is determined by the three-weeks' preparation from a computer and the click of a mouse in the multiple choice section; 50 minutes

of our students' inauthentic, formulaic, half-baked, unrevised writing? Why do we allow “people who can't get jobs elsewhere," "the dregs of the working world, the... 'unhirables"” to change our students' futures with a flimsy audit of a sliver of their writing (Farley 227)?

The reality is that these billion dollar testing corporations have no interest in reading the work of, responding to, or educating our student writers; their "tools," scorers, are made to "obey" rubrics that lead to profits by preying on our societal dependence on ranking, accountability, objectivity, and reliability; our distrust of teachers, their expertise, professionalism, and subjectivity (Farley 19; Reimagining 20, 50-1). Luckily for us, we need not choose between the time-old objectivity and subjectivity dichotomy, as Pearson would have us believe. Instead, we can implement "rhetorical writing assessment," that considers the value of the writing based on its intended purpose, rather than "subjectively" basing a score "on an individual's ability to construct the text she is reading" (Broad 12-13). Through this rhetorical lens, our students' high-stakes portfolios could appear drastically different in "genre, data, tone, and topic" based on student writers" "knowledge needs, interests, and choices" (Broad 15), and that's okay because there is "no single writing ability." Ultimately teaching students to "selfinitiate," "self-select" rhetorically valuable performances can create more valid and valuable 
assessment results and teach them the essential purpose of writing in a democratic society (Broad $15)$.

\section{Trust Our Teachers}

Our students deserve better than "an essay scoring machine" (Reimagining 21) because “entrusting the education of this country's children to 'professional scorers' in far distant states instead of the men and women who stand in front of their classrooms each day is about as smart an idea as entrusting your health not to the doctor holding a stethoscope to your heart but to some accountant crunching numbers in Omaha" (Farley 242). In other words, teachers are not "villains to be held accountable through... testing" (Rethinking 135); they are "the guy who's looking me in the eye" (Farley 242), highly-experienced, educated, invested experts whose judgements and educative feedback cannot be replaced before, during, or after the assessment.

If that is the case, then why do we allow Pearson to blindly lead the future of our democracy with their damaging assessments of our student writers?

Chris Gallagher and Eric Turley answer, “Unfortunately, teachers' professional judgment is not often viewed with the same respect as is a doctor's or a lawyer's. Instead of investing in the development of teachers' professional judgement, many educational reforms over the past couple of decades have been aimed at restricting, circumventing, or even replacing that judgment" (51). We have been conditioned to see teachers as less than professionals who cannot even prepare students for high-stakes assessment, second to the supposedly objective, safe preparation and scorers that the SAT promises. In other words, we allow Pearson to control our assessments, even though we suspect they might be faulty, because, foolishly, we trust Pearson more than we trust our own teachers. 
By comparison, the world of eventing can serve as a model when it comes to respecting our teachers' judgement. When it comes to dressage scores, riders are aware that their judge has formulated an "opinion" about their skills (GASP!), but his or her professional judgement is trusted because the scores "are the solid product of a judge's educated, experienced opinion, anchored in pages of carefully thought out Federation Equestre Internationale and United States Equestrian Federation rules, standards, and regulation" (Burkhardt 11). The high level of professional expertise that dressage judges are expected to acquire before entering the judge's stand can be likened much to the rigorous training certified teachers must complete before entering a classroom. Teachers of writing are expected to complete a four-year degree that focuses on pedagogy and content expertise, meet state licensure requirements which may include standardized tests like edTPA, ${ }^{7}$ and complete a series of clinical experiences that are supervised by qualified professors and teachers, with at least a full semester of student teaching. After becoming licensed, teachers must complete 120 hours of professional development, from approved providers, every five years in order to maintain their license ("License Renewal"). Teachers also acquire a "practical wisdom won from inquiry" in their everyday practice through the process of trying new techniques in the classroom and improving them (Gallagher and Turley 71). English teachers' hard-earned professional judgement should be viewed as irreplaceable and essential in preparing for and assessing high-stakes assessment, in the same way dressage judges are the ultimate authorities in the ring, before, during and after the show.

Beyond becoming a professional expert, dressage judges are expected to hold a personal "responsibility and dedication" to the sport (Burkhardt 11). They influence "...training trends by virtue of what they reward and penalize, and most take this responsibility seriously. Most feel

\footnotetext{
${ }^{7}$ Also administered by Pearson.
} 
that they play an important role in keeping the sport of dressage moving forward and on the correct path” (Bryant 249). Likewise, stakeholders in writing assessment, including teachers, administrators, school boards, college admissions teams, are shaping what our students believe about writing through what we allow Pearson to reward and penalize on our standardized writing assessments. At the moment, we are penalizing students' authentic writing processes; careful consideration of audience and purpose; recursive, purposeful revision; and individual, divergent, creative writing styles. Instead, we are rewarding single-draft, undercooked writing in one genre that is born from a mere three weeks of preparation; convergence with formulaic organizational strategies; and the dismissal of writing's rhetorical purpose, including any consideration of how the writing will impact a reader. We have a responsibility to reimagine our standardized writing scene to promote "what matters most": "form[ing] writers in healthy ways" (Reimagining 46-7).

\section{Conclusion}

There is a way to reroute, towards "growth in the right direction," where "the healthy and sustainable growth of young writers within an inclusive and equal democracy" is the focus of our assessments (Reimagining 51). Eventing assessment can give us a good starting point for reimagining large-scale writing assessment: our students need a robust and safe learning opportunity that provides multiple samples of their writing that teaches them about the real "transaction between writer, text, and reader" (Reimagining 108) and invites qualified, dedicated teachers to respond with personal, educative feedback as part of their overall growth and development as writers.

In order to "get on with the revolution," teachers must first earn the trust of their students by confronting fear in their classrooms, as I explored in chapter two, and then bear the 
responsibility "to themselves and their profession to ensure that state- and nationally-mandated systems are reasonable and fair" and humane "in all senses" (Hewitt 166). They must "beg for time," "lots of time," to "wrestle with the questions of what goes into writing portfolio and how it should be assessed" and time "to allow the system to take route" (Hewitt 193, 197, 195). The good news is that "...millions of teachers have what it takes" (Reimagining 12) to design and implement this type of modernized, beneficial, humane assessment system. So let them. 


\section{CHAPTER IV: CODA: HUMANS ARE THE MAGIC}

At the beginning of this project, I questioned the unexplainable, Elbovian "magic" in teaching and riding and writing and assessing, and now, I'm convinced that the "magic" in these spheres is the people involved: the teachers, coaches, writers, and riders and the intimate interactions between them as we teach and write and ride and assess and live. I am also convinced that the equestrian world has done a better job of embracing that hard-to-capture magic: in this community, we recognize that teaching another person to positively influence a 1200-pound animal with freewill to sail over obstacles with the help of a few flimsy pieces of leather and the strength of our thighs is sort of superhuman and voodoo-esque. We also urgently confront and normalize the fears that come with the magic of riding because we all know that, in no uncertain terms, riding is scary a lot of the time. We respect that our riding coaches each have a unique flare and style, and that's what makes them exceptional. ${ }^{8} \mathrm{We}$ also respect the qualified judges at national competitions who we trust to provide an accurate depiction of our performance on that given day and educative feedback to help us improve with our coach at home. Overall, riders and their coaches are cool with the uncapturable, unquantifiable, and totally mesmerizing interactions between the rider and horse, the horse and coach, the coach and rider, the judge and coach, and the rider and judge.

Meanwhile, we refuse to face the magical art of teaching and writing and assessing in our classrooms because we have been told by the factory-model of education and Pearson that efficiency and objectivity are what will lead to real progress and real safety in our classrooms. We've been lied to by forces that reduce teachers to assembly-line technicians whose primary

\footnotetext{
${ }^{8}$ One of my favorite local coaches says in almost every lesson, "There are a million roads to Rome; this just happens to be the one that works for me and my horses, so give it a go."
} 
job is to produce a certain number of goods, aka supposedly unfeeling students, and we've been denied the opportunity to experience and embrace the magic and intimacy and subjectivity of teaching, assessing, and writing. We've made it impossible for students and teachers to "fall in love with.... writing" and language in violent, scary factories (Because Writing 1063). ${ }^{9}$

Without that magic, we simply cannot reach our goal of creating strategic, effective, rhetorically-savvy writers. Instead, we've created fearful teachers and students who tip-toe through the "what" of our classrooms without ever addressing the "who," our students and their development as sensitive, sometimes fearful, eventually confident writers; the "why," the stakes of writing opportunities and the way language impacts real readers; and the "how," specific transferable strategies that students put in their "quiver" to use in rhetorical situations far beyond classrooms.

Not all is doomed. Maja Wilson says, “... I maintain that there are still spaces left in education - in our relationships with the students in our care, in our conversations with colleagues and parents, and in our political participations - for us to resist, to protest, and even to reimagine assessment," classroom spaces, "and our own profession. I believe that we have a personal, professional, and civic responsibility to do so" (Reimagining xxiv-xxv). I agree, and I believe the teaching of riding can help us, teachers of writing, reimagine the magic of our craft in the following ways. We must acknowledge fear in our writing classrooms: fear of being dismissed, fear of the writing process, fear of teachers, fear of grades, fear of readers, etc. Protecting the sacred community of writers and the micro-community between the teacher and student writer allows our students to know and trust each other and us. It also allows us to

\footnotetext{
${ }^{9}$ The parenthetical citations given for Because Writing Matters correspond with the Kindle eBook edition's location numbers rather than page numbers.
} 
humanize the delicate magic of assessment within our local classroom scene. Once we've earned our students' and communities' respect and trust in our local classrooms as a result of our fearreducing, confidence-building, humanizing work, we can finally take our seat at the large-scale assessment table and transform our currently detrimental SAT into an educative, ethical learning opportunity for our students in partnership with our expert teachers who can be valued as necessarily and powerfully subjective, magical readers. In other words, we cannot possibly tackle the broken, miseducative large-scale assessment scene until we address the local impacts of our factory-model of education and start shining a light on the magic of our craft in our own classrooms. The safety and confidence we instill in our students in our classrooms every day as valuable people teaching other valuable people to string magical words together in specific rhetorical spaces will ultimately allow students and other stakeholders to know us, then trust us, then allow us to do our job for the benefit of their student writers when it comes to high-stakes assessments.

\section{Writing Matters}

At this point, it's clear the teaching and assessing of writing and riding share a common goal: to shape strategic, effective, confident writers and riders who can navigate the complex and personal world of language and horses to reach a specific, relevant, high-stakes goal. The stakes for riders and their coaches is concrete and unignorable: the rider must ride strategically and confidently when facing real obstacles in order to keep the physical body safe. Yet, I argue that the stakes for writers and their teachers are even higher: as a society, we must have secure and effective writers who can independently use nuances in language to create change in our 
democratic world, so we must become "stewards" for change in our writing classrooms (Because Writing 87).

In Because Writing Matters, the National Writing Project makes a similar argument, saying that writing is the "the most important academic skill students need to develop in their secondary and postsecondary education" (354) for a variety of reasons. Logistically, being effective writers can make students hirable and desirable in their professional careers: "In today's business world, writing is a 'threshold skill' for both employment and promotion. In a 2004 survey of 120 major American corporations, respondents emphasize that people who cannot write and communicate clearly will not be hired and are unlikely to last long enough to be considered for promotion" (Because Writing 474-494). Beyond helping students secure jobs and promotions, the NWP says learning and implementing strategic writing strategies fosters the type of critical thinkers that we need "as adult citizens in the real world beyond school" (Because Writing 1434). These strategies "include examining assumptions and prior knowledge, posing questions, making inferences and interpreting, establishing working hypotheses and testing interpretations, and finally, imagining - which is perhaps the most powerful gateway of all, the foundation for original discovery and insight" (Because Writing 1434). As I write, I'm thinking of all the important documents that shape our daily lives that were dreamed up by strategic writers - ones like our Declaration of Independence. Our democratic society continues to crave writers who are able to "understand various modes of communication," "take on multiple tasks," "thinking critically," and "imbue... a core set of values" through use of language as "productive and prosperous citizens in the twenty-first century" (Because Digital 147).

The writers we need are not illustrious myths, and they're not going to descend from the heavens above - they're sitting in our classrooms, and writing teachers have a responsibility to 
our world to teach them the "to construct knowledge through analysis, synthesis, and interpretation" (Because Writing 1316). In other words, our job is much bigger than working through mandated curriculum, earning high statewide test scores, appeasing parents and administrators and school boards, and teaching kids writing "rules." Yes, these pressures are very real parts of the political scene teachers enter each day, but teachers of writing must first be "stewards" who are dedicated to teaching students "the ecology of writing and communication and, indeed, what is means to write - to create and compose and share" (Because Digital 87, 4).

\section{Essential Values in Our Writ[Rid]ing Spaces}

If we are to do this incredibly nuanced, essential, human, intimate work of teaching and assessing writing well, as I've outlined in chapters two and three, the NWP says teachers should embed the following belief into our classroom discourse: "Writing is a complex activity; more than just a skill, it is a means of interfacing with ideas and with the world, and a mode of thinking and expressing in all grades and disciplines" (Because Digital Writing Matters 16). This brings us back to our connection to riding, as Denny Emerson describes the art of learning to ride as being "like an onion," a complex process that riders must patiently and diligently learn "one tiny layer at a time" (Emerson 77). Students can accomplish this, like riders do, and "move beyond rote learning and simply reproducing information, facts, dates, and formulae" (Because Writing 623) if their teacher commits to the following:

- Teach students "writing-as-process" (Because Writing 924). Teachers of writing must reframe the writing curriculum to consider what happens as writers write, to "grapple with the messiness of composing itself," instead of solely valuing students' final draft, as the factory-model of education would like us to. Similarly, Emerson describes the act of 
learning to ride as "so slow and imperceptible that we are too close to see it on a day-today basis," "like watching grass grow" (Emerson 78). He stresses that riders must enjoy the tedious and exhausting process of learning and riding, rather than getting impatient, angry, and greedy with themselves and their horse. In this way, scholars in both fields echo that writing and riding are not "things" that are produced on a conveyor belt in five simple steps; they are both intimate, slow, messy, exhausting, lived acts of "inquiry, problem solving, and discovery" that "can help writers," and I argue riders, "move from subjective knowing toward a shared inquiry and intersubjective truth" (Because Writing 668; Mathieu 176). This connects to my findings in chapter two related to teaching students to recognize the fears and emotions they face throughout the act of writing and to embrace the natural, human, subjective, magical process that is learning to write, and ride, well.

- Teach students to "analyze and understand the rhetorical situation for their writing" (Because Digital 43). This supports Deborah Dean's case for creating "strategic writers" who have a real purpose and audience in mind when they approach the writing process and "create[s] reflective, flexible, and self-aware writers" who are capable of entering and adjusting to any writing scene effectively (Because Digital 43). In the same way, "not all horses are created equal," so a competent rider must be flexible and responsive to each individual horse's needs (Emerson 61). As I explored in chapter two, we need to teach students skills they can use to ride any "horse," so to speak, meaning they are able to enter any rhetorical situation beyond our classroom and write effectively. Similarly, when we assess their writing in a large scale setting, we must give students authentic 
rhetorical situations to write and revise within, as developed in my case for large scale portfolio assessment in chapter three.

- Teach students to "write to learn" (Because Digital 42). This means showing students that writing isn't always for an outside audience, for show, or for a final purpose at all; it is "a tool for documentation, inquiry, reflection and analysis of rich content" that can be used to "explore" ideas that would not have been possible to think up without the act of writing itself (Because Digital 42; Writing With Power 100). This is the equivalent of riders not always setting out to drill new skills into their horse or into themselves; instead riders must "get out of the ring and put on miles... out in the woods and play all day and have fun and learn stuff' (Emerson 151). In other words, both learning to ride and write require students to simply engage in the magical act and use it as a tool for learning, for fun, for reflection, and growth. We must diligently teach our students to engage in lowstakes writing to "question their own assumptions and reflect critically" and "work out thoughts and feelings for [them]selves alone" (Because Writing 623; Writing With 100).

- Teach students to view themselves as lifelong writers (Because Digital 62). The focus of our curriculum and our assessments shouldn't be teaching students the way to write, but instead, teachers should help students "discover what works best for them in a variety of writing tasks" as "real," independent writers (Because Writing 942). This also means showing students that "writing is never mastered once and for all; it is a lifelong, communicative mode of learning whose craft and processes must be adapted for distinct purposes and contexts," and they will need to continue honing their skills in rhetorical situations far beyond our classrooms, just like we, as their teachers, do (Because Writing 668). Riders share this belief that our riding "quiver" is never full, that we must always 
learn new riding tactics to effectively ride the unique, live animal that we are riding on that particular day (Emerson 186). We can accomplish this work of framing writing as a lifelong process by helping students confront their fears of writing, of audience, of being graded, of teachers within our writing classrooms and by coaching them through (and assessing) a large scale portfolio assessment that supports their overall growth and development as rhetorical writers.

In order to move away from teaching, writing, learning, and assessing in scary, inhumane, ineffective factories, our students, their families, our administrators, and communities must realize the stakes of our work; they must believe that writing matters. We, as classroom teachers, must also recognize the importance of our work and embed the values discussed above into our everyday teaching and assessment practices. Doing so can motivate all stakeholders to give us the resources, time, and respect we need to teach and write and assess well, as riders do, to protect our democratic safety, like a rider's physical safety, in our world today.

\section{What's Next?}

Within this exploration of the complex and dynamic spheres of writing and riding, there are further areas that could open additional surprises and tensions. Below are potential areas for research within this framework.

\section{Emotional Labor and Financial Stress of Being a Teacher and Equine Professional}

In both spheres, there is an exhaustion culture where teachers and horse professionals often struggle financially and emotionally with the burden of caring for their students and/or horses. An article called "Horse Industry Pros on What They Wish They'd Known Earlier" 
surveys top riders, and they echo the sentiment that in horses, you have to "put your head down and be prepared to work your behind off" and burden "immense financial pressure" (Law). In terms of reward, horse professionals recognize "fame, money or title," isn't in the cards for them, much like teachers. Instead horse pros must find gratification in "mak[ing] a horse feel better, help[ing] them do something they struggled with before, even sav[ing] a life on occasion" (Law). This reminds me of how teachers must enter a field knowing they'll never have a huge paycheck or societal respect or prestige while "pour[ing] their lives into other people's children every day" (Murray). ${ }^{10}$ More research is needed into the motivations, rewards, inequity, and challenges associated with the emotional labor and the inherent selfsacrifice in both roles.

\section{Teacher as Writer, Expert, Learner}

In addition to teaching his or her students, the riding coach is also almost always also a rider, a trainer (teacher of horses), and a lifelong learner who seeks coaching from another horse professional. In the teaching of writing, it seems lesson common to view the teacher as a writer, a craftsman, an expert, or a learner. Instead, we get stuck in the singular role as "teacher," which is detrimental when we are trying to build trust and ethos with our students and other stakeholders. They must see us as more than public servants built to meet their needs.

The National Writing Project has been at this work of building "respect for [expert] teachers" and their "special knowledge" by creating opportunities for teachers of writing to 1) develop their craft as writers and 2) teach other teachers what works in his or her classroom

${ }^{10}$ This can be found in Murray's dedication to his book Personal and Authentic. 
(Gray xii-xiii). Doing so gives teachers the sense of their own "authority and expertise" (Gray xii) and empowers them to inhabit other valuable roles beyond "teacher" and "giver to students." I would like to research ways to embed this philosophy into professional development in schools, not just at an isolated, short-term writing institute over the summer. For example, my schools designates one-hour per week for PLC (Professional Learning Community) time. Currently those meetings with my department are most often unproductive, stressful, and/or simultaneously anxiety-inducing. What would happen if English departments, and maybe others too, spent this PLC time sharing their writing and teaching strategies with one another in spirit of the National Writing Project?

\section{Social Justice in Writing and Riding}

In riding, we teach students about horse management and foster empathetic conversations about care, responsibility, paying attention, stewardship, sustainability, etc. Many young riders join the United States Pony Club, an organization that hosts learning opportunities for riders to embody their core values: horsemanship, including "respect to healthcare, nutrition, stable management, handling and riding a mount safely, correctly and with confidence"; teamwork, "including cooperation, communication, responsibility, leadership, mentoring, teaching and fostering a supportive yet competitive environment"; respect for horses, self, land, service, and teamwork; service through local, regional, and national "volunteerism"; and education "to achieve personal goals and expand knowledge through teaching others" (“About Pony Club”).

I argue that our writing classrooms should hold and promote the same values that are listed above, and I'm interested in how practicing teachers can embed these into their daily 
instructional and assessment norms. Mollie Blackburn's book lifts teachers' experiences of doing this work in their classrooms, of preparing their students to "work within and against their communities" and "bravely support students' rights" as they write (105). She also argues for the value of connection between students, teachers, communities, like I do in this thesis, and the value of "healing," "humanizing," and standing in "solidarity" (109). After additional research, Blackburn's foundation for embedding these values of communal resistance and assistance in our writing classrooms could be bolstered in connection to the USPC's core values.

\section{Gamification in the Writing Classroom}

Sally Cochran and Jane Wallace, two scholars who've written about teaching riding, both argue that gamifying instruction, "mak[ing] a game of it" is essential to shaping "secure, happy and confident" riders (Cochran 80; Wallace 92). Their arguments for gamification stem from valuing student engagement: "anything involving some good-natured rivalry is 'in' with [students]" (73); building a positive relationship with students: "being boring isn't going to encourage anyone!" (Cochran 84); and improving the rider's skills: playing "pretend games" to "improve control, balance and confidence" (Wallace 81).

How can we, as teachers of writing, embed gaming into our instruction and potentially assessment practices? Particularly, I'm wondering about the type of rewards gamers experience when they play - it's not about "winning"; it's about the intrinsic feeling of success that gamers feel when they overcome a challenge within the game (Farber 57). Farber calls it "fiero, the Italian word that describes what one feels after overcoming a difficult challenge"; "the ultimate intrinsic reward for accomplishment" (59). Of course it would be wonderful to 
play games as part of our instructional strategies, but this seems to relate more deeply to the writing process itself. It's necessary for students to feel failure and challenge in the "writing game" for them to hit this state of "fiero" and ultimately gain the "grit and persistence" needed to develop into an effective, strategic writer (Farber 60). In terms of honoring emotions throughout the writing process, like I describe in chapter 2, games can be a powerful access point for feelings of fear, surprise, disgust, pleasure/pride, gloat, wonder (Farber 60). How can we encourage students to recognize and regulate those emotions and normalize their role in the mental, emotional, logistical, and spiritual game that is writing well?

\section{Freewrit[rid]ing}

I whole-heartedly believe Denny Emerson, leader in riding, and Peter Elbow, major figure in the teaching of writing, absolutely must go to coffee at least once to discuss their philosophies about how writing and riding happens as a lived experience that requires "freewriting," as Elbow calls it (Writing With 13), or "saddle time" if you're asking Emerson (38). At the heart of both perspectives is the idea that the magical acts of writing and riding require the writer or rider to experience the simple act of putting words on paper or your butt in the saddle as much as possible to learn "in practice, not just in theory" what it means to write and ride (Writing With 14). Emerson says riders must view themselves as athletes that embody "strength, agility, balance, fitness/stamina/endurance, and quickness" (111). Likewise Elbow says writers must write quickly and agilely when free-writing, like "push-ups" that build the strength to "get on with it" when putting words on paper (14).

The ultimate goal of Elbow and Emerson's ideas is that the rider and writer become "centaurs": "an integral part of the living, breathing horse," or text, "almost as if the spinal 
column of the horse merges with the spinal column of the rider to create on entity" (Emerson 120). Elbow talks about this "mysterious, underground" process of becoming one with words too: "Freewriting gives practice in this special mode of focusing-but-not-trying; it helps you stand out of the way and let words be chosen by the sequence of the words themselves or the thought, not by the conscious self. In this way freewriting gradually puts a deeper resonance or voice into your writing" (Writing With 16). Taking the time to develop "feel" and "natural responses" and "fluency" with horses and/or words is what makes the best "highly trained" riders and writers (Emerson 124, 129; Writing With 16).

I'm enamored by this connection between two brilliant minds that I admire in separate fields and would like to see further investigation into how their core beliefs about writing and riding come together and pull apart. ${ }^{11}$

\section{Hop On: Come Write With Me}

Embracing these seemingly separate intersections of my identity has allowed me to see the craft of teaching writing in new and surprising ways. Before writing, the underlying fear in my classroom was invisible to me, as I was busy bounding through curriculum and hurrying from bell to bell like most practicing teachers. I was also frustrated and annoyed by the SAT preparation and administration practices in my building but couldn't articulate what bugged me. Similarly, in the arena, I had yet to realize just how often I'm called to confront my own fear as

\footnotetext{
${ }^{11}$ Although I've identified more specific connections between the fields of writing and riding, other fields can and should be brought into these future conversations about emotional labor, teacher-as-expert-learner, social justice, gamification, freewriting. For example, my colleague Clinton Soper is interested in how practices in kendo, his hobby, can complement and contradict our work in the writing classroom. I look forward to more research between and among the spheres that make up our daily experiences and can illuminate our work as writing teachers in new and interesting ways.
} 
a rider and the fears of my students as their coach. I also was unaware that my sport was assessing my riding skills in well-rounded ways by high-quality judges and providing me educative feedback to use at home. Revealing the value of eventing assessment has allowed me to question and reimagine what our high-stakes assessment in writing could look like for our students.

Putting the fear in our classrooms and high-stakes assessment in conversation with one another has revealed that one reason why teacher experts are not inherently a part of the largescale assessment conversation is that stakeholders in education, including our students, have learned to push us away because of unintentionally scary norms in our schools and writing classrooms. To make meaningful change for the good of our democratic society, we must first build the trust of our students within our classrooms in the ways I outline in chapter two and create change that integrates teacher experts into our large-scale assessment practices as I explore in chapter three.

In the same way that humans are the key to unlocking magic in our classrooms, enabling and embracing unique parts of our identities as teacher-researchers can provide new insights into our already substantial, scholarly conversation about how to teach and assess better in today's world. I call more teacher-researchers to employ the "theory of complementarity" so that "a new frontier of sociological explanation found through links between traditional interests," like the teaching of writing, "and those usually ignored by such analysis," like the teaching of riding (Star 81). By inviting our external "communities of practice" that envelop us in our daily lives into this professional dialogue about our teaching of writing (Star 102), we can identify common problems and solutions and complicate and illuminate the "patchwork" of our beautifully magical, human, intimate craft (Broad 11; Star 82). 


\section{WORKS CITED}

“About Eventing.” Land Rover Kentucky Three-Day Event, kentuckythreedayevent.com/abouteventing/.

“About Pony Club.” Pony Club, www.ponyclub.org/About.aspx.

"Become an SAT Scorer." SAT Suite of Assessments, collegereadiness.collegeboard.org/sat/k12-educators/score-sat-essays.

Blackburn, Mollie. Adventurous Thinking: Fostering Students' Rights to Read and Write in Secondary ELA Classrooms. National Council of Teachers of English, 2019.

Broad, Bob and Michael Boyd. "Rhetorical Writing Assessment: The Practice and Theory of Complementarity.” Journal of Writing Assessment, vol. 2, no. 1, 2005.

Bryant, Jennifer. The USDF Guide to Dressage. Storey Publishing, 2006.

Burkhardt, Barbara. Dressage from A to X: The Definitive Guide to Riding and Competing. Trafalgar Square Publishing, 2004.

Dewey, John. Experience and Education. Kappa Delta Pi, 1938.

Cochran, Sally. Teaching Horseback Riding Lessons: A Practical Training Manual for Instructors. Equine Kingdom Publishing Company, 2016.

Dean, Deborah. Strategic Writing: The Writing Process and Beyond in the Secondary English Classroom, 2nd Edition. National Council of Teachers of English, 2017.

“Dressage Judges Training Program.” United States Equestrian Federation, usef.org/formspubs/-Te1QDgcsbQ/dressage-judge-training-program---senior.

Elbow, Peter. Embracing Contraries: Explorations in Learning and Teaching. New York, Oxford UP, 1986. Print.

Elbow, Peter. Writing Without Teachers. New York, Oxford UP, 1998. Print. 
Elbow, Peter. Writing With Power: Techniques for Mastering the Writing Process. New York, Oxford UP, 1998. Print.

Elbow, Peter and Pat Belanoff. "Portfolios as a Substitute for Proficiency Examinations." Assessing Writing: A Critical Sourcebook, edited by Brian Huot and Peggy O'Neill, Bedford/St.Martin's, 2009, pp. 97-101.

Emerson, Denny. How Good Riders Get Good: Daily Choices That Lead to Success in Any Equestrian Sport. Trafalgar Square Books, 2011.

"Eventing Officials." United States Eventing Association, useventing.com/education/officials.

Farber, Matthew. Gamify Your Classroom: A Field Guide to Game-Based Learning (New Literacies and Digital Epistemologies). International Academic Publishers, 2014.

Farley, Todd. Making the Grades: My Misadventures in the Standardized Testing Industry. Berrett-Koehler Publishers, 2011.

Gallagher, Chris W. and Eric D. Turley. Our Better Judgement: Teacher Leadership for Writing Assessment. National Council of Teachers of English, 2012.

Grant-Law, Leslie. "Horse Industry Pros on What They Wish They'd Known Earlier." Horse Sport, www.phttps://horsesport.com/unfiltered-eventing/horse-industry-pros-on-whatthey-wish-theyd-known-earlier/onyclub.org/About.aspx.

Gray, James. Teachers at the Center: A Memoir of the Early Years of the National Writing Project. Berkley, National Writing Project, 2006.

Haraway, Donna. "Situated Knowledges: The Science Question in Feminism and The Privilege of Partial Perspective." Technoscience: The Politics of Interventions, edited by Kristin Asdal, Unipub, 2007, pp. 109-131. 
Hewitt, Geof. A Portfolio Primer: Teaching, Collecting, and Assessing Student Writing. Heinemann, 1995.

Hillocks Jr., George. "Fighting Back: Assessing the Assessments.” English Journal, March 2003. pp. 63-70.

Holaday, Lynn. "Writing Students Need Coaches, Not Judges.” Alternatives to Grading Student Writing, edited by Stephen Tchudi, NCTE, 1997, pp. 35-46.

Huot, Brian. "Toward a New Theory of Writing Assessment.” College Composition and Communication, vol. 47, no. 4, pp. 549-566.

"Inside the Test." SAT Suite of Assessments, collegereadiness.collegeboard.org/sat/inside-thetest.

The Illinois Balanced and Restorative Justice Project. "Restorative Circles in the Classroom." School Improvement Day, 17 January 2020, Dunlap High School, Dunlap, IL.

Inoue, Asao B. "Community-based assessment pedagogy." Assessing Writing, vol. 9, 2005, pp. 208-238.

KhanAcademy, https://www.khanacademy.org/.

"License Renewal Chart for Public Schools." Illinois State Board of Education, isbe.net/Documents/license-renewal-chart.pdf.

Mathieu, Paula. "Reviewed Work: Writing as a Way of Being: Writing Instruction, Nonduality, and the Crisis of Sustainability by Robert P. Yagelski." Composition Studies, vol. 42, no. 2, pp.175-178.

Moss, Pamela. “Can There Be Validity without Reliability?” Educational Researcher, vol. 23, no. $2,1994$. 
Murray, Thomas C. Personal \& Authentic: Designing Learning Experiences That Impact a Lifetime. IMPress, 2019.

National Writing Project. Because Digital Writing Matters: Improving Student Writing in Online and Multimedia Environments. Jossey-Bass, 2010.

National Writing Project. Because Writing Matters: Improving Student Writing in Our Schools. Kindle ed., Jossey-Bass, 2010.

"SAT Essay Scoring." SAT Suite of Assessments, collegereadiness.collegeboard.org/sat/scores/understanding-scores/essay.

"SAT Prep." The Princeton Review, www.princetonreview.com/college/sat-test-prep.

“Scores." SAT Suite of Assessments, collegereadiness.collegeboard.org/sat/scores.

“Should I Retake the SAT?" College Board, blog.collegeboard.org/should-i-retake-sat.

Smith, Dominique, et al. Better than Carrots or Sticks: Restorative Practices for Positive Classroom Management. Alexandria, ACSD, 2015.

Smith, Dominique, et. al. "A Restorative Climate for Learning." Educational Leadership, March 2018, pp. 74-78.

Spangler, Susan J. Bloome, et. al. "Making Statewide Writing Assessment Rigorous, Valid, and Fair: The Illinois State Portfolio Assessment of Writing (ISPAW)." Illinois English Bulletin, vol. 91, no. 3, 2004, pp. 11-28.

Star, Susan Leigh. "Power, Technology and the Phenomenology of Conventions: On Being Allergic to Onions." Technoscience: The Politics of Interventions, edited by Kristin Asdal, Unipub, 2007, pp. 79-107. 
Thiel, Jay. "Allowing Our Wounds to Breathe: Emotions and Critical Pedagogy." Writing and Teaching to Change the World: Connecting with Our Most Vulnerable Students, edited by Stephanie Jones, Teachers College Press, 2014, pp. 36-48.

Wallace, Jane. Teaching Children to Ride: A Handbook for Instructors. Kenilworth Press, 2006.

Wachtel, Ted, et al. Restorative Justice Conferencing: Real Justice \& The Conferencing Handbook. Bethlehem, International Institute for Restorative Practices, 2010.

Wiggins, Grant. Educative Assessment: Designing Assessments to Inform and Improve Student Performance. Jossey-Bass, 1998.

Williamson, Michael. “The Worship of Efficiency: Untangling Theoretical and Practical Considerations in Writing Assessment." Assessing Writing: A Critical Sourcebook, edited by Brian Huot and Peggy O’Neill, Bedford/St.Martin's, 2009, pp. 57-80.

Wilson, Maja. Reimagining Writing Assessment: From Scales to Stories. Heinemann, 2018.

Wilson, Maja. Rethinking Rubrics in Writing Assessment. Heinemann, 2006.

Yancey, Kathleen Blake. "Looking Back as We Look Forward: Historicizing Writing Assessment." Assessing Writing: A Critical Sourcebook, edited by Brian Huot and Peggy O’Neill, Bedford/St.Martin's, 2009, pp. 131-149.

Zehr, Howard. The Little Book of Restorative Justice. New York, Good Books, 2015. 


\section{APPENDIX A: SAMPLE DRESSAGE RUBRIC}
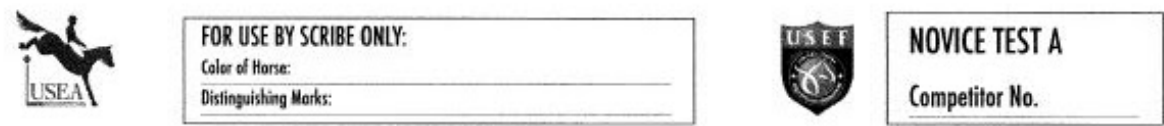

2014 UNITED STATES EQUESTRIAN FEDERATION, INC. NOVICE EVENTING TEST A

(For Novice Level Horse Trials and Combined Tests)

\begin{tabular}{|c|c|c|c|c|c|c|}
\hline & TEST & DIRECTIVES & REYARKS & POINTS & $f$ & TOTAL \\
\hline 1. $\hat{c}$ & $\begin{array}{l}\text { Galer wriking hat. } \\
\text { Irack laft warking trat }\end{array}$ & Strieghenes, belanes in Iun, thythr. & $\begin{array}{l}\text { Some wearing on } \\
\text { C-line }\end{array}$ & $6 \cdot 5$ & & \\
\hline 2. $\mathrm{E}$ & $\begin{array}{l}\text { Cinde belt } 20 \text { neters } \\
\text { diameter wutking rot. }\end{array}$ & Wryttm, tend end balance. Shape of circle. & $\begin{array}{l}\text { Good Achurty } \\
\text { vostradion hund }\end{array}$ & 6.5 & & \\
\hline 3. $\mathrm{FMH}$ & Clonge rein wokkisg troc. & Balases ord hiphen in turrs. & Tignt toplane & 6.57 & & \\
\hline 4. 8 & $\begin{array}{l}\text { Grate ight } 20 \text { maters } \\
\text { diantet. }\end{array}$ & Rhofthe, bend ard telence, thape of cirche. & $\begin{array}{l}\text { Foin Activity } \\
\text { stiff bend }\end{array}$ & 6.5 & & \\
\hline 5. A & Modiun wolk & Eost of truasition, quelily of wolk. & $\begin{array}{c}\text { puiling to walk, } \\
\text { ugstead) }\end{array}$ & 6.0 & & \\
\hline 6. 1004 & Free wolk. & Sirech and relantien, qualiy of walk & $\begin{array}{l}\text { rair swins jues down streten } \\
\text { laces do }\end{array}$ & 6.5 & $x 2$ & \\
\hline 7. $\mathrm{N}$ & Nedun walk. & Queliey of trasshive end wak. & faitly acher & 17.0 & & \\
\hline 8. ${ }_{E-B}$ & $\begin{array}{l}\text { Wuking bat. } \\
\text { Helf dirde laft } 20 \text { mowers } \\
\text { mothitg frot. }\end{array}$ & 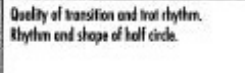 & Four connection & 7,0 & & \\
\hline 9. Approcing & Wenking conar leh leed & tane end tabace of trondition. & hesitant & 7.0 & & \\
\hline 10.8 & Gireb lafi 20 meters. & Rlbythn otd bahatea, shape of corche & fluid & -7.5 & & \\
\hline $\begin{array}{l}\text { II. Batmeen B } \\
\text { end X }\end{array}$ & Worting ire. & Eass ond balates ie itrenifion. & lacks straightors & 6.5 & & \\
\hline 12. $118 \mathrm{~F}$ & Chenge nein warking toat. & Streightmess ard cuality of trut. & almost straight & 7,0 & & \\
\hline 13. AnF & $\begin{array}{l}\text { Working trot. } \\
\text { Hoff tirte right } 20 \text { neters } \\
\text { workirg troe. }\end{array}$ & 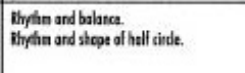 & rictly uphill & 7.5 & & \\
\hline 14. Approstive & Werking conler righte lead. & Gace end todence of trenition. & Sone resistance & 6.0 & & \\
\hline 15.8 & Creth right 20 meters. & 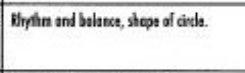 & $\begin{array}{l}\text { fair junp } \\
\text { netas bond }\end{array}$ & 7.0 & & \\
\hline 16. Aetwen 1 & Wodkitg tres. & Ease atd bahatee of hrtasifion & & 8.0 & & \\
\hline 17. A & Tun dem center line. & Pabose is tum, wrightmess & faisy fiv & 7,0 & & \\
\hline it. $x$ & hat, Salute. & tess of trataihien, inmatility. & $\begin{array}{l}\text { corrected } \\
\text { to striaght }\end{array}$ & 7,0 & & \\
\hline
\end{tabular}

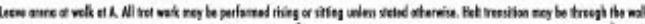

Collective Marks: TO R i ht whesen in hambe try to strayter I

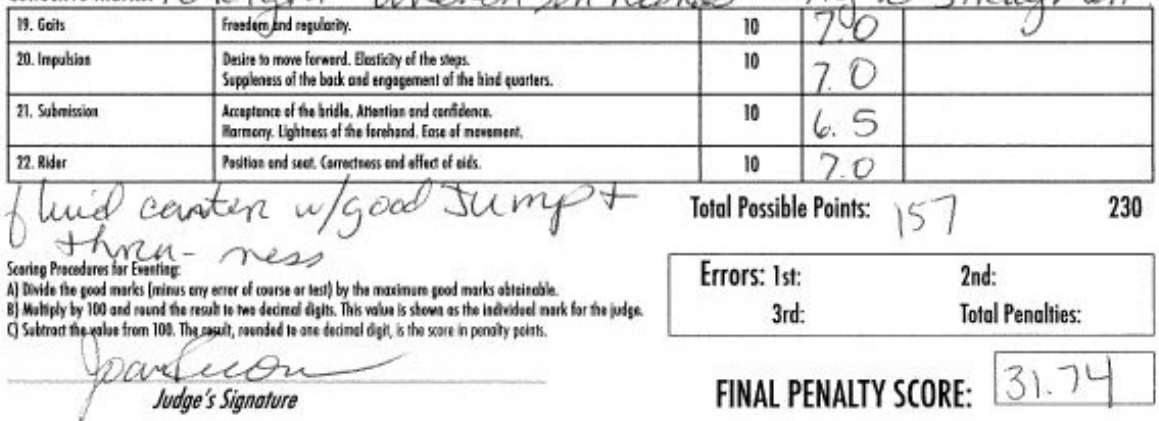

